\title{
Late Quaternary dynamics of the Lambert Glacier-Amery Ice Shelf system, East Antarctica
}

Li Wu${ }^{1}$, David J. Wilson², Rujian Wang ${ }^{1^{*}}$, Sandra Passchier ${ }^{3}$, Wout Krijgsman ${ }^{4}$,

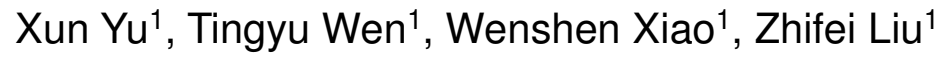

1. State Key Laboratory of Marine Geology, Tongji University, Shanghai, China 2. Institute of Earth and Planetary Sciences, University College London and Birkbeck, University of London, London, UK

3. Department of Earth and Environmental Studies, Montclair State University, Upper Montclair, New Jersey, USA

4. Department of Earth Sciences, Utrecht University, Utrecht, The Netherlands

Corresponding author

Dr. Rujian WANG

State Key Laboratory of Marine Geology, Tongji University

1239 Siping Road, Shanghai, 200092

P.R.China

Tel \& Fax: 0086-21-65984880

E-mail: $\underline{\text { rjwang@tongji.edu.cn }}$ 


\section{Abstract}

The Lambert Glacier-Amery Ice Shelf system (LGAISS) is the largest outlet glacier system in East Antarctica but its response to past climate variability is poorly constrained. In this study, we explore its dynamics over the last $\sim 520$ thousand years using new high-resolution sedimentary records retrieved off Prydz Bay. Episodic occurrences of iceberg rafted debris indicate a dynamic ice sheet throughout this interval, while changes in clay mineral compositions provide detailed evidence on the waxing and waning of the LGAISS. Our data indicate that advance and retreat of the LGAISS was sensitive to oceanic forcing, but also responded to local summer insolation when insolation peaks combined with interglacial sea level high stands. Subglacial bed topography may have played an additional role in modulating the LGAISS behaviour, which could explain sectoral differences in the response of the East Antarctic Ice Sheet to climate change. Overall, our records indicate that the LGAISS advanced more extensively during previous late Quaternary glacial periods than during Marine Isotope Stages 2 and 4. Furthermore, the LGAISS retreated more significantly than present during Marine Isotope Stage 13, and only moderately during Marine Isotope Stage 7, which suggests that the duration of warm climatic states could be a key factor affecting the dynamics of the East Antarctic Ice Sheet.

Key words: Quaternary; glaciology; Antarctica; Prydz Bay; Lambert Glacier-Amery Ice Shelf System; ice sheet dynamics; clay minerals; iceberg rafted debris

\section{Introduction}

The East Antarctic Ice Sheet (EAIS) contains a sea level equivalent of $\sim 53$ metres, of which around a third is marine-based ice (Fretwell et al., 2013). Although ongoing climate warming is not expected to induce complete collapse of the EAIS, marine margins of the EAIS with landward-deepening beds appear susceptible to ice loss (Schoof, 2007; Cook et al., 2013; DeConto and Pollard, 2016; Scherer et al., 2016; Golledge et al., 2017a; Wilson et al., 2018; Blackburn et al., 2020), with significant implications for future sea level rise. The dynamic response of the EAIS to climate change is gaining increasing attention, but it remains uncertain due to complex subglacial topography and the potential for different behaviour in different EAIS sectors (Golledge et al., 2017a; Pittard et al., 2017; Morlighem et al., 2020). Given discrepancies in future global sea level projections (e.g. Golledge et al., 2015; DeConto and Pollard, 2016; Bakker et al., 2017; Edwards et al., 2019), better constraints on past changes in the EAIS are required to provide calibration targets for modelling studies.

Repeated advance and retreat of marine-based margins of the EAIS have 
been inferred in different periods of the geological past from sporadic proximal Antarctic records (e.g. Naish et al, 2001; Grützner et al., 2003; Williams et al., 2010; Passchier, 2011; Cook et al., 2013; Patterson et al., 2014; Wilson et al., 2018). These studies indicate that the EAIS was dynamic and capable of responding to a spectrum of climatic forcing. However, high-resolution records are scarce due to a lack of suitable sediment sequences and difficulties in age model construction. This situation limits our ability to constrain the forcing factors that contributed to past advance and retreat of the EAIS. In particular, high-resolution records that span multiple late Quaternary glacial-interglacial cycles from sites proximal to the EAIS are rare, despite the fact that similar ice sheet boundary conditions to the modern day and relatively well-constrained evidence on global sea level and climatic forcing make this interval a critical target for exploring EAIS dynamics (DeConto and Pollard, 2016; Wilson et al., 2018). Hence, better geological constraints from this period could significantly improve projections of future global sea level rise.

In this study, we present high-resolution proxy records of ice sheet dynamics, including iceberg rafted debris (IRD) and clay mineralogy, from two well-dated gravity cores, ANT30/P1-02 (P1-2) and ANT29/P5-03 (P5-3), retrieved from the continental rise off Prydz Bay, East Antarctica (Fig. 1A). In combination with previously published sedimentological and geochemical analyses on cores from this region (Wu et al., 2017; 2018; 2019; 2020), our major goal is to reconstruct the dynamic behaviour of the Lambert Glacier-Amery Ice Shelf system (LGAISS) and to explore its forcing during the late Quaternary. The LGAISS originates in the Gamburtsev Mountains of central East Antarctica, with ice thicknesses of $\sim 2500 \mathrm{~m}$ in the Southern Prince Charles Mountains and $\sim 400 \mathrm{~m}$ at the seaward edge of the Amery Ice Shelf (Shipboard Scientific Party, 2001). It is the largest marine-based outlet glacier system in East Antarctica, draining $\sim 15 \%$ of the EAIS, equivalent to $\sim 8 \mathrm{~m}$ of global sea level (Rignot et al., 2019). Therefore, its dynamic behaviour is linked to changes in the mass balance of a significant portion of the EAIS. There have been two Ocean Drilling Program (ODP) expeditions (Legs 119 and 188) to this area, and a number of studies have demonstrated dynamic behaviour of the LGAISS since at least the Oligocene (e.g. Ehrmann, 1991; Hambrey et al., 1991; Hambrey and McKelvey, 2000; Grützner et al., 2003; Passchier et al., 2003; Junttila et al., 2005; Passchier, 2011). To date, however, there has been no study constraining the LGAISS dynamics across multiple late Quaternary glacial-interglacial cycles, and this study fills this crucial gap.

\section{Regional setting}

Prydz Bay is the largest embayment around East Antarctica with an area of around $80,000 \mathrm{~km}^{2}$. It is situated between $65^{\circ} \mathrm{E}$ and $80^{\circ} \mathrm{E}$, facing the Indian Ocean sector of the Southern Ocean, at the seaward terminus of the Lambert Graben, which is occupied by the LGAISS (Fig. 1). The LGAISS is a 
rock-walled marine-based glacier system that occupies a long and relatively thin embayment with a number of significant pinning points (Fretwell et al., 2013; Pittard et al, 2017). In the present day, the LGAISS is grounded $\sim 500 \mathrm{~km}$ upstream from the seaward edge of the Amery Ice Shelf (Shipboard Scientific Party, 2001).

The Lambert Graben is Mesozoic or older in age, but the underlying geology of the Prydz Bay region reflects the Pan-African Prydz Belt of late Neoproterozoic to early Cambrian age (Fig. 1B). Metamorphism and magmatism at this time was linked to the final amalgamation of Gondwana, which brought together an Archaean craton in the southern Prince Charles Mountains and several Neoproterozoic terranes to the north (Wilson et al., 1997; Boger et al., 2001; Liu et al., 2006; Van Leeuwen et al., 2019). As such, most of the basement is composed of medium- to high-grade Precambrian metamorphic and intrusive igneous rocks (Trail and Macleod, 1969; Mikhalsky et al., 2001), with isolated exposures of Paleozoic granite, mafic dykes, Permian sediments, Paleogene volcanics, and Oligocene and younger sediments near the coast (Tingey, 1991; Webb and Fielding, 1993; Hambrey and McKelvey, 2000; Ehrmann et al., 2003). Sedimentary rocks are exposed sporadically along the flanks of the Lambert Graben, stretching for a distance of $\sim 500 \mathrm{~km}$. Some of the best-documented sediments are those of the Permo-Triassic Amery Group and the Neogene Pagodroma Group, which are both exposed in the Northern Prince Charles Mountains (Fig. 1B). The Amery Group sediments are fluvial in origin and more than $2000 \mathrm{~m}$ thick, comprising sandstones and siltstones with a kaolinite matrix (Webb and Fielding, 1993). The glaciomarine Pagodroma Group sediments comprise four geographically separated formations, namely the Mount Johnston Formation; the Fisher Bench Formation; the Battye Glacier Formation; and the Bardin Bluffs Formation (Whitehead and McKelvey, 2001; Ehrmann et al., 2003). The clay assemblages of the Mount Johnston Formation and the Fisher Bench Formation are similar, being dominated by illite and chlorite. In contrast, sediments of the Battye Glacier Formation additionally contain significant kaolinite and smectite. The Bardin Bluffs Formation has the greatest kaolinite concentrations, relatively low illite and chlorite concentrations, and lacks smectite (Ehrmann et al., 2003).

The continental shelf in Prydz Bay slopes landward, with water depths ranging from $\sim 200-400 \mathrm{~m}$ over the continental shelf break to $\sim 600-1000 \mathrm{~m}$ over the inner shelf (Fig. 1A; Shipboard Scientific Party, 2001; Fretwell et al., 2013). Repeated advance and retreat of the LGAISS in the past has left a series of glacial geomorphic features in this region, such as grounding zone wedges, glacial depressions, and mega-scale flutes and lineations (Leitchenkov et al., 1994; Domack et al., 1998; Passchier et al., 2003; Theissen et al., 2003; Hannah, 2006; O'Brien et al., 2007). The SE-NW orientated Prydz Channel (Fig. 1A), with a width of $\sim 150 \mathrm{~km}$, a length of $\sim 200 \mathrm{~km}$, and a water depth of $\sim 600 \mathrm{~m}$, represents the largest product of glacial erosion across the 
continental shelf and serves as the major drainage pathway for ice streams derived from the LGAISS (Shipboard Scientific Party, 2001). The Prydz Channel probably formed during the late Miocene to early Pliocene when the LGAISS periodically began to expand to the shelf break, leading to the development of the Prydz Channel Fan as a trough-mouth fan that extends to $\sim 2400 \mathrm{~m}$ water depth on the continental slope (Shipboard Scientific Party, 2001; Passchier et al., 2003).

Average sedimentation rates of the late Quaternary ( $<780 \mathrm{ka})$ succession on the Prydz Bay continental slope and rise range from 0.7 to $1.3 \mathrm{~cm} / \mathrm{kyr}$ at ODP Sites 1165 and 1167 (Theissen et al., 2003; Junttila et al., 2005) and at several gravity core sites, including ANT30/P1-02, ANT30/P1-03, and ANT29/P4-01 (Tang et al., 2016; Wu et al., 2017) (Fig. 1A). Marine surface sediment in the region is characterised by a high illite content and low chlorite content, while a high smectite content is found mainly around Kerguelen Plateau, and kaolinite is rich in glacial-aged sediments on the continental shelf offshore of the LGAISS (Borchers et al., 2011) (Fig. 1A).

The ocean current system around Prydz Bay is complex (Fig. 1A) and is summarised based on a number of studies (Nunes Vaz and Lennon, 1996; Bindoff et al., 2000; Yabuki et al., 2006; Mathiot et al., 2011). The Antarctic Coastal Current flows westward over the shelf, bringing in cold waters from the east. The Antarctic Slope Current also flows westward, driven by the Southern Easterly Winds, but over the continental slope. Between the Antarctic Coastal Current and the Antarctic Slope Current, the clockwise-rotating Prydz Gyre mainly flows over the continental shelf. North of the Antarctic Slope Current, the cyclonic Antarctic Divergence Zone represents a series of mesoscale eddies that form under the shear stress of the Southern Westerly and Easterly Winds. It can also intrude onto the shelf, thereby supplying water from the relatively warm and salty Circumpolar Deep Water (CDW), which subsequently interacts with shelf waters and can potentially lead to bottom water formation. Further offshore, the Antarctic Circumpolar Current flows eastwards and connects the Southern Ocean with the other ocean basins.

\section{Materials}

This study used two gravity cores ANT29/P5-03 (P5-3) and ANT30/P1-02 (P1-2) that were collected during the $29^{\text {th }}$ and $30^{\text {th }}$ Chinese Antarctica Expeditions onboard R/V Xuelong in 2012-2013 and 2013-2014, respectively (Table 1). The southern core P5-3 is located at a water depth of $2576 \mathrm{~m}$ on the lower Prydz Channel Fan, and the northern core P1-2 is located on the continental rise near the lower margin of the Prydz Channel Fan at a water depth of $2860 \mathrm{~m}$ (Fig. 1A). In these locations, sediment supply is dominated by pelagic deposition and downslope transport from the proximal shelf (Passchier et al., 2003; Junttila et al., 2005). Sediment provenance is therefore expected to be sensitive to the dynamics of the LGAISS. Some geochemical and 
sedimentological analyses have been conducted previously on core P1-2 (Wu et al., 2017, 2018, 2019, 2020), while data from core P5-3 are reported here for the first time.

Based upon visual description, smear slide inspection, and wet sieving, sediment from the two cores primarily consists of silt-clay with a minor coarse fraction $(63-2000 \mu \mathrm{m})$ and sparsely distributed dropstones ( $>2 \mathrm{~mm})$. Two distinct sediment facies alternate throughout the cores, separated by gradual transitions: a diatom-bearing (10-25\%) mud with an olive/light brown colour and weak bioturbation, and a diatom-barren (<10\%) silty-clay with a grey colour and no bioturbation (Fig. 2). Core P1-2 contains six diatom-bearing units (S1-S6) and five diatom-barren units (D1-D5), while only four diatom-bearing units (S1-S4) and three diatom-barren units (D1-D3) occur in the shorter core P5-3. Carbonates are generally absent, except for intervals with $<15$ wt.\% carbonate (Wu et al., 2019) that are composed of planktonic foraminifer Neogloboquadrina pachyderma (sin.) (Nps) at 86-177 cm and 214-246 cm in core P1-2, and at 56-145 cm and 172-201 cm in core P5-3 (Fig. 2). No obvious hiatuses were found throughout the cores.

In addition to these two cores, other sediment cores referred to in this study are shown in Fig. 1A and/or listed in Table 1. It should be noted that core ANT30/P1-03 which spans the last 500 kyr (Tang et al., 2016; Wu et al., 2017) is located very close to the site of core P5-3 (Fig. 1A), but we used core P5-3 in this study because core material from core ANT30/P1-03 was unavailable.

\section{Methods}

\subsection{Experimental methods}

The major experimental methods used in this study were measurements of IRD abundance and lithology, and clay mineralogy. In addition, in order to derive a reliable age model for the new core P5-3 by inter-core correlations, colour reflectance measurements, XRF geochemical scanning, AMS ${ }^{14} \mathrm{C}$ dating, and magnetic susceptibility logging were also conducted on core P5-3. Except for magnetic susceptibility, such data were previously published for core P1-2 (Wu et al., 2017, 2019). The AMS ${ }^{14} \mathrm{C}$ dating and the magnetic susceptibility logging were conducted at BETA Analytic Inc., Miami, USA and at the First Institute of Oceanography, State Oceanic Administration, Qingdao, China, respectively. All other measurements were performed at State Key Laboratory of Marine Geology, Tongji University, Shanghai, China.

Magnetic susceptibility (kappa volume specific, with $\mathrm{C}$ and $\mathrm{F}$ sensor) was derived from non-destructive physical parameter core scanning using a GEOTEK Multi-Sensor Core Logger (MSCL) on whole cores at $0.5-\mathrm{cm}$ increments. Detailed methodology and parameter settings for the MSCL were described by Weber et al. (1997).

Colour reflectance was measured using a Minolta spectrophotometer CM-2002 at 1-cm increments. To prevent oxidation, the cores were tightly 
sealed immediately after collection and stored below $2^{\circ} \mathrm{C}$ for less than a month. Cores were then split into two halves and the working half was covered by a thin transparent film, which was adjusted to tightly fit the smooth split core surface, before measurement once the cores had reached room temperature. The Minolta spectrophotometer CM-2002 provides quantitative measurements of the visible light spectrum from $400-700 \mathrm{~nm}$ and automatically transfers it into the CIE La*b* colour space (Nagao and Nakashima, 1992). All spectra were measured relative to a black background and a standard white plate made with barium sulphate under a standard illumination. In this study, only the colour parameter $\mathrm{a}^{*}$, which represents colour changes from green to red, is used.

Core scanning X-ray fluorescence (XRF) measurements were obtained on the split core surface of the archive half of each core using an AVAATECH XRF core scanner. The split core surface was covered with a spex certiprep 3532 Ultralens foil (4 $\mu \mathrm{m}$ thick) to protect the probe of the scanner from contamination and to avoid desiccation of the sediment. A Pd filter was placed in front of the incoming $X$-ray beam and measurements were taken at $1-\mathrm{cm}$ increments with a size of $1.5 \mathrm{~cm} \times 1 \mathrm{~cm}$. Each core was triple-scanned for elements from $\mathrm{Al}$ to $\mathrm{Ba}$ at $1 \mathrm{~mA}$ and at different tube voltages $(10 \mathrm{kV}, 30 \mathrm{kV}$, and $50 \mathrm{kV}$ ) with $30 \mathrm{~s}$ counting time. Further technical details on the XRF core scanner are described in Richter et al. (2006).

Clay mineral analyses were carried out on the $<2 \mu \mathrm{m}$ fraction, which was separated based on Stokes' settling velocity law, after removal of carbonate by treatment with $0.5 \mathrm{~N} \mathrm{HCl}$ (Liu et al., 2003; 2007). Analysis was performed on oriented mounts using a PANalytical X'Pert PRO diffractometer with CuKa radiation and $\mathrm{Ni}$ filter, under a voltage of $45 \mathrm{kV}$ and an intensity of $40 \mathrm{~mA}$. Three XRD runs were performed, following air-drying, ethylene-glycol saturation for $24 \mathrm{~h}$, and heating at $490{ }^{\circ} \mathrm{C}$ for $2 \mathrm{~h}$. Identification and interpretation of clay minerals were conducted according to a comprehensive comparison of three multiple X-ray diffractograms obtained under different measurement conditions (Liu et al., 2003; 2007). Semi-quantitative calculations of the parameters for each peak were carried out on the glycolated curve using MacDiff software (Petschick, 2000). The relative contents of each clay mineral species were estimated mainly according to an area of (001) series of basal reflections (Holtzapffel, 1985). Kaolinite and chlorite were discriminated according to the relative proportions given by a ratio of the 3.57 $\AA$ and $3.54 \AA$ peak areas (Holtzapffel, 1985).

Iceberg rafted debris is defined here as the weight percent of the 154-5000 $\mu \mathrm{m}$ non-biogenic fraction in the dry bulk sediments (Passchier, 2011). It was measured at 2-cm intervals following procedures described by Wang et al. (2013). Briefly, 10-15 g dry sediments were soaked in deionised water for 2 days, and $\mathrm{H}_{2} \mathrm{O}_{2}$ was added if necessary to help disaggregate the sample. The sample was then wet-rinsed through a $63 \mu \mathrm{m}$ mesh, and the $>63 \mu \mathrm{m}$ residue was dried under $55^{\circ} \mathrm{C}$ and sieved through $154 \mu \mathrm{m}$ and $250 \mu \mathrm{m}$ meshes. Since the $>250 \mu \mathrm{m}$ fraction is rare or absent in most of the samples, we did not 
measure it specifically, and weighed the entire 154-5000 $\mu \mathrm{m}$ fraction (after removal of carbonate if necessary). The mass accumulation rate (MAR) of IRD was calculated according to Teitler et al. (2010) and Patterson et al. (2014) as follows:

$$
\text { IRD MAR = IRD wt.\% } \times \text { LSR } \times \text { DBD }
$$

where IRD wt.\%, LSR, and DBD are the IRD weight percent, linear sedimentation rate, and dry bulk density, respectively.

The lithologies of IRD grains in core P1-2 were identified and counted under a binocular microscope at 4-cm increments, based on the $>250 \mu \mathrm{m}$ fraction (Wang et al., 2013). The $>154 \mu \mathrm{m}$ fraction was used when grains $>250$ $\mu \mathrm{m}$ were scarce. More than 250 grains were counted for each sample. We identified and counted quartz, crystalline rock fragments, and mafic rock fragments. Chert, garnet, mica, and feldspar were also identified and counted, but those data are not shown here because of their low concentrations and discontinuous occurrence (Figures DR1 and DR2). The crystalline rock fragments include granites and metamorphic rocks, but we did not distinguish them further because of the small grain sizes. Images of IRD grains were obtained using a camera installed on a microscope and using a field emission-scanning electronic microscope (FE-SEM, TESCAN Mira 3, Czech), and the elemental composition of IRD grains was analysed using energy-dispersive spectroscopy (EDS, Oxford Ultim Max40). The samples were coated with gold before FE-SEM and EDS analyses.

The lithologies of 20 dropstones $(>5 \mathrm{~mm})$ from core $\mathrm{P} 1-2$ were also identified and sorted into three groups i.e., granites, metamorphic rocks, and mafic rocks (Figure DR1). The granite group was identified based on a mineral composition of mainly quartz, feldspars (plagioclase and/or orthoclase), and mica (muscovite and/or biotite), with minor hornblende and a lack of an orientation structure. The metamorphic rock group was identified mainly based on the presence of an orientation structure and/or typical metamorphic minerals such as garnet, while the mafic rock group was identified based on its (crypto-)crystalline structure and dark colour.

Radiocarbon $\left({ }^{14} \mathrm{C}\right)$ dating was performed on shells of the planktonic foraminifera $N$. pachyderma (sin.) (Nps) (>154 $\mu \mathrm{m}$ size fraction) from four intervals of core P5-3 (i.e., $60-62 \mathrm{~cm}, 82-84 \mathrm{~cm}, 114-116 \mathrm{~cm}$, and 204-206 cm), using Accelerator Mass Spectrometry (AMS). The ${ }^{14} \mathrm{C}$ ages were calibrated to calendar ages using the Calib 7.0 program (Stuiver and Reimer, 1993) and the Marine 13 radiocarbon age calibration curve (Reimer et al., 2013) with a marine reservoir age of $1300 \mathrm{yrs}$ (Domack et al, 2001).

\subsection{End Member Modelling Analysis on the clay mineral dataset}

End Member Modelling Analysis (EMMA) is an inversion algorithm that aims to construct physical (linear) mixing models which express the input data as mixtures of a limited number of end-members (EMs) with realistic compositions (Weltje, 1997). It has proven to be a powerful tool for 
decomposing sediment compositional datasets (e.g. grain size, elemental geochemistry) into their constituent end-members. There are various algorithms for EMMA (e.g. Weltje, 1997; Dietze et al., 2012; Paterson and Heslop 2015; Yu et al., 2016), which typically produce similar results for the same dataset (Paterson and Heslop, 2015). In this study, the algorithm of Weltje (1997), which has been coded as an R-based program 'RECA' (Seidel and Hlawitschka, 2015), was used and a three-EM model was selected (see Section 6.1) to decompose the clay mineral dataset of both sediment cores ( $N$ $=466$ ). Parameters input to 'RECA' to compute the three-EM model solution were as follows: number of end-members $=3$; convexity threshold $=-6$; number of iterations $=100$; weighting exponent $=0.5$. We also ran the same clay mineral dataset $(\mathrm{N}=466)$ using the EMMA algorithm of Paterson and Heslop (2015), which has been made as a MATLAB ${ }^{\circledR}$-based software 'AnalySize', and obtained the same results as those from 'RECA', supporting the robustness of our results.

\section{Age models}

\subsection{Radiocarbon ages}

For core $\mathrm{P} 5-3$, one AMS ${ }^{14} \mathrm{C}$ age falls into Marine Isotope Stage (MIS) 2 $(27,625 \mathrm{yr}$ BP at $60-62 \mathrm{~cm})$, and another falls into MIS $3(42,067 \mathrm{yr}$ BP at 82-84 $\mathrm{cm})$, with the caveat that the latter age is close to the ${ }^{14} \mathrm{C}$ dating limit $(\sim 43,500$ yr) (Table 2). Deeper samples from 114-116 cm and 204-206 cm are older than the ${ }^{14} \mathrm{C}$ dating limit $(\sim 43,500 \mathrm{yr})$. This observation is similar to findings from core $\mathrm{P} 1-2$, where samples at $136 \mathrm{~cm}$ and below were beyond the ${ }^{14} \mathrm{C}$ dating limit (Table 2). Based on the AMS ${ }^{14} \mathrm{C}$ ages, linear sedimentation rates for core P5-3 were $1.4 \mathrm{~cm} / \mathrm{kyr}$ for the $83-61 \mathrm{~cm}$ interval and $>2.2 \mathrm{~cm} / \mathrm{kyr}$ for the $61-0 \mathrm{~cm}$ interval. The latter sedimentation rate represents a lower limit based on an assumed core top age of zero, because the core top could have been lost during coring. These sedimentation rates are slightly lower than similar ${ }^{14} \mathrm{C}$-based estimates for core P1-2 over a similar interval (i.e. $3.3 \mathrm{~cm} / \mathrm{kyr}$ between $115-0 \mathrm{~cm})$.

\subsection{Age model for core P1-2}

Oxygen isotope stratigraphy is typically used to construct age models for marine sediment cores on orbital timescales, but poor carbonate preservation limits the application of this technique in the Southern Ocean (Pugh et al., 2009; Weber et al., 2012; Xiao et al., 2016). In our recent study (Wu et al., 2017), export production records in sediment cores retrieved off Prydz Bay were found to be closely coupled with global climate change. We therefore aligned the export production records of three Prydz Bay cores (P1-2, P1-3, and P4-1; Fig. 1A and Table 1) to LR04- $\delta^{18} \mathrm{O}$ (Lisiecki and Raymo, 2005), using a dynamical programming technique (Lisiecki and Lisiecki, 2002), to derive age models on orbital timescales (Wu et al., 2017). Radiocarbon dating 
on the upper parts of the cores was consistent with such alignment (Wu et al., 2017). For core P1-2, we use the age model from Wu et al. (2017), which indicates that it extends back to $\sim 523$ ka (MIS 13) with an average sedimentation rate of $\sim 1.2 \mathrm{~cm} / \mathrm{kyr}$ (Figs. 3A-B).

\subsection{Age model for core P5-3}

The age model of the new core P5-3 was constructed by matching geochemical and sediment property records of core P5-3 to their counterparts in core $\mathrm{P} 1-2$, in combination with the ${ }^{14} \mathrm{C}$ dating constraints. Specifically, alignment was made by simultaneously matching the XRF scanning $\mathrm{Ba} / \mathrm{Al}$, $\mathrm{Ca} / \mathrm{Al}$, magnetic susceptibility, and colour $\left(\mathrm{a}^{*}\right)$ records (Figure DR3), which are regionally comparable in different sediment cores (Pugh et al., 2009; Weber et al., 2012; Wu et al., 2017, 2019). Visual identification and matching of features between the two cores provided age controls (i.e., pattern matching age controls) for core P5-3 (Table 3). Some age controls can be identified in multiple sediment property records, while some are only robust in a particular record. We identified 14 pattern matching age controls in total, while the two AMS ${ }^{14} \mathrm{C}$ age control points are also morphologically compatible in the sediment property records (Figure DR3).

The age controls from pattern matching, in combination with the AMS ${ }^{14} \mathrm{C}$ ages and an assumed core top age of zero, were used to derive the age model of core P5-3 by linear interpolation (Fig. 3A). Considering the orbital-scale resolution of our records, we suggest that the assumption of a core top age of zero is acceptable, as it is only likely to introduce an age uncertainty of several thousand years. On this age model, the four records of core P5-3 (i.e., the XRF scanning $\mathrm{Ba} / \mathrm{Al}$ and $\mathrm{Ca} / \mathrm{Al}, \mathrm{a}^{*}$, and magnetic susceptibility) match well with their counterparts in core P1-2 (Figs. 3C-F). According to the age model, core P5-3 extends back to $330 \mathrm{ka}$ (MIS 9). The sedimentation patterns were similar between cores P5-3 and P1-2 (Fig. 3B), with both cores showing higher sedimentation rates during the transitions from glacial to interglacial periods, and similar average sedimentation rates $(0.9 \mathrm{~cm} / \mathrm{kyr}$ for core $\mathrm{P} 5-3,1.2 \mathrm{~cm} / \mathrm{kyr}$ for core P1-2). These sedimentation rates are similar to those estimated for gravity cores P1-3 (1.1 cm/kyr, Tang et al., 2016; Wu et al., 2017) and P4-1 $(0.9 \mathrm{~cm} / \mathrm{kyr}$, Wu et al., 2017) and the core top units at ODP Sites 1167 and 1165 (0.7 to $1.3 \mathrm{~cm} / \mathrm{kyr}$, Junttila et al., 2005; Theissen et al., 2003) (Fig. 1A), reflecting regional sedimentation patterns of Prydz Bay during the late Quaternary.

\section{Results}

\subsection{Clay mineralogy and EMMA}

Clay mineralogy is consistent between the two sediment cores (Fig. 4), supporting that the data are robust and that both sites were influenced by similar clay sources through time. Illite content varies between $42-73 \%$ with an 
average of $58 \%$. The illite records show prominent glacial-interglacial variations, with higher values during interglacial periods and lower values during glacial periods. Kaolinite content varies between 10-31\% with an average of $18 \%$. The kaolinite records also show glacial-interglacial cyclicity, with higher values during glacial periods (although muted during MIS 12) and lower values during interglacial periods. Smectite content varies between 4-38 \% with an average of $17 \%$, and chlorite content varies between $4-13 \%$ with an average of $8 \%$. Neither of those records shows consistent glacial-interglacial variability, although the smectite record shows some similarity to the kaolinite record. The highest smectite content and the lowest chlorite content both occur during MIS 12, corresponding to the glacial period with unusually low kaolinite content.

Summary statistics of the clay mineral dataset show that illite dominates the clay mineral composition, followed by lower but comparable levels of kaolinite and smectite, and minor chlorite (Fig. 5A). In EMMA, the minimum number of EMs required for a satisfactory approximation of the data is estimated by calculating the coefficients of determination $\left(R^{2}\right)$ (Weltje, 1997). Fig. 5B shows the $R^{2}$ values for each clay mineral species for models with two, three, or four EMs. The mean $\mathrm{R}^{2}$ of all clay mineral species, weighted by abundance, increases with increasing number of EMs (q) (Fig. 5C). The two-EM model (mean $R^{2}=0.91$ ) shows low $R^{2}$ for both smectite and chlorite, while the three-EM model (mean $R^{2}=0.984$ ), which represents the inflection point of the q-mean $R^{2}$ curve (Fig. $5 C$ ), shows low $R^{2}$ only for chlorite (Fig. 5B). Previous studies suggest that the true number of EMs for a dataset should correspond to the value of $q$ at the inflection point in the $q$-mean $R^{2}$ curve (Prins et al., 2002). In addition, to determine the suitable number of EMs in this study, the requirement for reproducibility of chlorite can be removed because it comprises only a small fraction of the data set (e.g. Stuut et al., 2014). The goodness-of-fit statistics thus demonstrate that the three-EM model provides the best compromise between $q$ and $R^{2}$.

The resulting compositions of the modelled EMs 1-3 are respectively illite-, kaolinite- and smectite-rich, although illite is a major clay mineral species in all three EMs (Fig. 5D). Consequently, their temporal distributions (Figs. 4F-H) are similar to those of the illite, kaolinite, and smectite abundances (Figs. $4 A-C)$.

\subsection{Iceberg rafted debris}

Iceberg rafted debris content varies between 0.1-43.3 wt.\% with an average of $4.7 \mathrm{wt} . \%$ in core P1-2, and between 1.0-29.4 wt.\% with an average of $8.1 \mathrm{wt} . \%$ in core P5-3 (Fig. 6A). The IRD MAR varies between 0.002-0.245 $\mathrm{gcm}^{-2} \mathrm{kyr}^{-1}$ (average $0.045 \mathrm{gcm}^{-2} \mathrm{kyr}^{-1}$ ) in core P1-2, and between 0.003-0.198 $\mathrm{gcm}^{-2} \mathrm{kyr}^{-1}$ (average $0.061 \mathrm{gcm}^{-2} \mathrm{kyr}^{-1}$ ) in core P5-3 (Fig. 6B). For the last 330 $\mathrm{kyr}$, the average IRD content and IRD MAR of the more proximal southern core P5-3 is slightly higher than that of the northern core P1-2 (8.1 wt.\% versus 4.8 
wt.\%, and $0.061 \mathrm{gcm}^{-2} \mathrm{kyr}^{-1}$ versus $0.050 \mathrm{gcm}^{-2} \mathrm{kyr}^{-1}$, respectively). In core P1-2, IRD mostly occurs during late interglacial and early glacial periods, with single peaks during MIS 13-12 and MIS 11-10 transitions, and double peaks during MIS 9-8 and MIS 7-6 intervals. In core P5-3, there are also IRD peaks during late interglacial and/or early glacial periods, but this core additionally displays higher IRD content during interglacials. In general, both cores record low IRD content during transitions from late glacial to early interglacial periods.

The IRD in core P1-2 is predominantly composed of quartz (>85\%), crystalline (granitic and metamorphic) rock fragments (average $\sim 5 \%$ ), and mafic rock fragments (average $\sim 0.4 \%$ ) (Figs. $6 \mathrm{C}-\mathrm{F}$ ). Similar to previous observations from Prydz Bay shelf sediments (Domack et al., 1998), two varieties of quartz are distinguishable in core P1-2. There is a clear quartz, which is usually angular to subangular (Figs. 7A-C), and a slightly reddish iron-stained quartz, which is typically subrounded to rounded (Figs. 7D-F). Higher proportions of iron-stained quartz compared to clear quartz (Figs. 6C-D) generally correspond to intervals with higher IRD abundance and IRD MAR (Figs. 6A-B) and coincide with low proportions of crystalline and mafic rock fragments (Figs. 6E-F). The lithologies of the 20 dropstones (Fig. 6G) include granite $(55 \%)$, metamorphic rocks $(30 \%)$, and mafic rocks (15\%), and their temporal distributions appear random.

\section{Discussion}

\subsection{Proxies for LGAISS dynamics}

Both IRD and clay mineralogy have been widely used to infer past changes in Antarctic Ice Sheet dynamics (e.g. Junttila et al., 2005; Hillenbrand et al., 2009; Passchier, 2011; Weber et al., 2014; Patterson et al., 2014; Wilson et al, 2018). Ice rafted debris provides unambiguous evidence for the calving of debris-bearing icebergs from dynamic ice sheet margins, which is significant because the Antarctic Ice Sheet loses $~ 50 \%$ of its mass by iceberg calving (Depoorter et al., 2013). At proximal sites, clay minerals in the fine fraction are mainly derived from continental inputs and reflect weathering processes and source provenance (Ehrmann, 1991; Junttila et al., 2005; Borchers et al., 2011). Hence, fluctuations in clay mineral assemblages have been proposed to provide constraints on past changes in ice volume and/or grounding line position, including in the Amundsen Sea (Hillenbrand et al., 2009; Simões Pereira et al., 2020) and the Prydz Bay region (Junttila et al., 2005; Passchier, 2011; Borchers et al., 2016). For both IRD and clay mineral records, a careful consideration of sediment provenance and transport processes is required in order to associate variability with the dynamics of a specific glacier system.

\subsubsection{Iceberg rafted debris}

Coarse sediments in high-latitude marginal settings typically indicate the deposition of IRD, but could also result from bottom current winnowing of the 
fine fractions of the sediment. These two types of coarse fraction can be distinguished by comparing the coarse fraction content to the sorting parameter of the fine fraction (Passchier, 2011). Peaks of the coarse fraction that coincide with well-sorted sediments are likely to reflect a concentration of coarse material following winnowing of fine-grained sediments by high energy bottom currents, whereas peaks linked to poorly sorted material likely record IRD events superimposed on the background hemipelagic sedimentation (Passchier et al., 2003; Passchier, 2011; Patterson et al., 2014). In core P1-2, there is a positive correlation between the IRD MAR (Fig. 8D) and the sorting parameter of the $<154 \mu \mathrm{m}$ fraction (Fig. $8 \mathrm{~F})(\mathrm{r}=0.62, \mathrm{~N}=312$ ), with almost every IRD peak corresponding to a peak in the sorting parameter, which indicates poorer sorting. In addition, in both cores, similar downcore patterns between the IRD abundance and IRD MAR (Figs. 8D-8E) indicate that the IRD records were not significantly affected by variations in sedimentation rate that could reflect sediment winnowing and/or focusing (Ó Cofaigh et al., 2001). We therefore conclude that the IRD records provide a robust signal of iceberg-derived inputs.

Since relatively warm sea surface temperatures restrict iceberg transport from more distal parts of East Antarctica (Teitler et al., 2010; Passchier, 2011; Cook et al., 2014), IRD records in Prydz Bay are expected to predominantly reflect changes in the proximal LGAISS. Indeed, argon-argon dating of IRD grains in Prydz Bay indicates a local origin for core top sediments (Roy et al., 2007), although some Pliocene IRD at ODP Site 1165 (Fig. 1A) was far-travelled from Wilkes Land and may have been linked to ice sheet destabilisation in the Aurora Subglacial Basin (Williams et al., 2010; Cook et al., 2014). While we are unable to fully constrain possible changes in IRD supply from Wilkes Land to Prydz Bay during the late Quaternary, the different phasing of IRD occurrence at our sites (Figs. 8D-E) compared to Site U1361 (Fig. 1A; Fig. 8C; Wilson et al., 2018) argues against a significant IRD source from the distant Wilkes Subglacial Basin. In addition, the lithology of the IRD and dropstones in core P1-2 supports a local origin because the assemblage of quartz, granite, metamorphic rock, and mafic rock (Fig. 6G) is consistent with the coastal geology of Prydz Bay (Fig. 1B). In particular, iron-stained quartz, which is abundant when IRD MAR is high (Fig. 6D), was likely derived from the Permo-Triassic fluvial red beds of the Amery Group in the Lambert Graben (Webb and Fielding, 1993; Domack et al., 1998; Fig. 1B). We therefore interpret our IRD records in terms of local dynamic behaviour of the EAIS in the Prydz Bay sector.

\subsubsection{Clay mineral provenance}

In the high-latitude Southern Ocean, typical clay mineral assemblages of illite and chlorite reflect physical weathering under polar conditions (Chamley, 1989; Ehrmann, 1991; Borchers et al., 2011). Illite is derived from the erosion of acidic rocks such as gneisses, granulites, and granites (Chamley, 1989; 
Ehrmann et al., 2003), while chlorite is derived from low-grade chlorite-bearing metamorphic and basic igneous source rocks (Chamley, 1989; Hillenbrand et al., 2003). These clay species may be deposited widely along the continental shelves of Antarctica and redistributed offshore by ocean currents (Borchers et al., 2011). In our downcore records, illite and chlorite are the dominant and minor clay species, respectively, consistent with their distributions in surface sediments (Fig. 1A) (Borchers et al., 2011) and in other sediment cores from the Prydz Bay region (e.g. Junttila et al., 2005; Borchers et al., 2016). Their relative abundances are likely linked to the predominance of illite- versus chlorite-producing source rocks in the Prydz Bay sector of East Antarctica (Ehrmann, 1991; Tingey, 1991).

In contrast, smectite and kaolinite are products of chemical weathering. Source rocks in East Antarctica contain high feldspar contents (Tingey, 1991), in principle making them suitable for kaolinite formation (Borchers et al., 2011). However, this process requires intense hydrolysis and only occurs under warm and humid conditions (Chamley, 1989), such that Quaternary occurrences of kaolinite in the polar regions must be recycled from old successions (Junttila et al., 2005; Hillenbrand et al, 2009; Borchers et al., 2011). In our study area, the Permo-Triassic fluvial sandstones of the Amery Group (Fig. 1B) comprise iron-stained quartz within a kaolinite matrix (Webb and Fielding, 1993), making them a likely source for both the iron-stained quartz in the IRD fraction and the kaolinite in the fine fraction (Ehrmann 1991). In addition, the Neogene Battye Glacier and Bardin Bluffs Formations of the Pagodroma Group, which are also exposed on the western flank of the Lambert Graben (Fig. 1B), contain significant kaolinite proportions (averaging $24 \%$ and $54 \%$, respectively), which may have been originally derived from the erosion of Amery Group rocks (Ehrmann et al., 2003). However, outcrops of the Pagodroma Group only cover a limited area in the Amery Oasis. In either case, these kaolinite-rich sediments could have been eroded by the ice sheet and deposited on the shelf, before being reworked and transported offshore. Indeed, kaolinite-rich sediments are a substantial component of the Oligocene and younger successions on the Prydz Bay continental shelf. For example, Oligocene sediments from ODP Sites 739 and 742 on the outer continental shelf (Fig. 1A) contain up to $60 \%$ kaolinite, while the overlying Plio-Pleistocene sediments comprise $\sim 20 \%$ kaolinite (Hambrey et al., 1991). These compositions may be indicative of a major subglacial source of kaolinite in the Lambert Graben, while also suggesting that erosion of the continental shelf during LGAISS advance (e.g. O'Brien et al., 2007) could enhance the offshore transport of kaolinite.

Smectite forms by hydrolysis in a range of environments characterised by slow movement of water (Chamley, 1989), but in the Southern Ocean it usually relates to volcanic environments (Ehrmann, 1991; Petschick et al., 1996). In the study area, the Battye Glacier Formation on the west flank of the Lambert Graben (Ehrmann et al., 2003) (Fig. 1B) and the Kerguelen Plateau (Borchers 
et al., 2011) (Fig. 1A) both represent potential sources of smectite.

In an illite-chlorite-kaolinite ternary plot (Fig. 9A), our downcore samples fall along a binary mixing line between modern slope sediment (illite-rich) and glacial (and some modern) shelf sediment off the LGAISS (kaolinite-rich), with interglacial samples richer in illite and glacial samples richer in kaolinite. In an illite-kaolinite-smectite plot (Fig. 9B), it is evident that sediments from Kerguelen Plateau must have contributed smectite to the core sites, especially during interglacial periods and MIS 12 (Fig. 4E). Overall, three distinctive sources of clay minerals can be identified, with illite-rich, kaolinite-rich, and smectite-rich sources corresponding to the three EMMA-derived EMs 1-3 (Fig. 9). The three EMs are therefore used to represent the average compositions of the three sources.

Of particular interest here is the kaolinite-rich source, or EM 2, which we suggest is derived from erosion and reworking of Amery Group and Pagodroma Group sediments by the LGAISS. The possibility of kaolinite-rich sediment input by the westward-flowing Antarctic Slope Current seems unlikely, because there is no known source of kaolinite in the regions east of Prydz Bay. In addition, oceanic transport from upstream should be linked predominantly to smectite supply from the Kerguelen Plateau (i.e. EM 3), as indicated by the smectite-rich characteristics of both the surface sediment (Borchers et al., 2011) and the sediment sequences from ODP Sites 738 and 744 (Fig. 1A) (Ehrmann, 1991). Based on the assumption that the transport of kaolinite to the continental slope mainly reflects reworking of sedimentary successions beneath the LGAISS, we propose a conceptual model that relates temporal variability in the abundance of kaolinite-rich EM2 to the dynamic behaviour of the LGAISS (Fig. 10), which is similar to a previous model for the Amundsen Sea region (Hillenbrand et al., 2009). During cold glacial periods, the LGAISS advanced northwards, which shortened the distance between the LGAISS grounding and calving lines and the continental slope, thereby enhancing the transport of kaolinite-rich EM2 to the core sites (Fig. 10B). Enhanced subglacial erosion of kaolinite from the continental shelf as the ice sheet expanded may have further added to the signal. During warm interglacial periods, the LGAISS retreated, resulting in reduced erosion of the shelf and an increased distance between the LGAISS margin and the core sites, and hence a significant reduction in EM2 supply to the continental slope and rise (Fig. 10A).

Because of the wide distribution and high abundance of illite in the study area (Fig. 1A), we take the illite-rich EM1 to represent the relatively stable background sedimentation and use EM2/(EM1+EM2) to infer the grounding line behaviour of the LGAISS. We suggest that the EM2/(EM1+EM2) ratio (Fig. 11D) is a superior proxy for LGAISS dynamics than conventional clay mineral ratios (e.g. kaolinite/illite) (Fig. 4E) because each clay mineral species has multiple sources (Fig. 5D). In particular, using this ratio excludes the effect of dilution by Kerguelen-sourced EM3 (Fig. 9). There is also no correlation in 
downcore records between the $E M 2 /(E M 1+E M 2)$ ratio and the sortable silt mean grain size (McCave and Andrews, 2019; Wu et al., 2020) ( $r=0.09, \mathrm{~N}=$ 146) (Figure DR4). This observation suggests that the EM2/(EM1+EM2) ratio is also independent of local bottom current speeds, with the caveat that sortable silt is an imperfect flow speed proxy in this setting. Therefore, an increase or a decrease in the $E M 2 /(E M 1+E M 2)$ ratio is interpreted in terms of advance or retreat of the LGAISS, respectively (Fig. 10).

\subsection{Dynamics of the LGAISS}

\subsubsection{Iceberg discharge through glacial-interglacial cycles}

The temporal pattern of an IRD record is a mixed signal that is ultimately determined by debris-bearing iceberg discharge but is further modulated by transport processes. Therefore, in addition to ice sheet dynamics, IRD records can reflect factors such as the debris content of icebergs, distance from iceberg source areas, ocean current pathways, and sea surface temperatures (Cowan et al., 2008; Teitler et al., 2010; Williams et al., 2010; Passchier, 2011; Cook et al., 2014; Weber et al., 2014).

Today, large Antarctic ice shelves such as the Amery lce Shelf usually lack basal debris, because most debris melts out close to the grounding line before calving (Death et al., 2006; Patterson et al., 2014; Smith et al., 2019). The operation of such basal melting processes could potentially explain the low IRD content and IRD MAR in our records during deglacial and early interglacial periods, including the Holocene (Figs. 8D-E). Although the LGAISS also contains significant sand-sized englacial and supraglacial debris, we suspect that warm ocean conditions during interglacials could have led to most of the IRD being released before such icebergs reached the core sites (e.g. Passchier, 2011). Rapid depletion of the IRD content of icebergs during their northwards transport could also help to explain the higher average IRD MAR and greater interglacial occurrence of IRD deposition in core P5-3 compared to core P1-2 (Figs. 8D-E). Despite the minimal IRD content during deglacial periods, the combination of high sedimentation rates and an elevated silt fraction (Figs. 8G-H) indicates that meltwater plumes were well developed and that intensive iceberg calving and glacial retreat were occurring at these times (Joseph et al., 2002).

Prominent peaks in IRD abundance and IRD MAR at our core sites mostly coincided with interglacial to glacial transitions and early glacial periods, when Antarctic temperatures were declining and local export production was decreasing (Figs. 8A, 8D, and 8E). Therefore, in this setting, IRD deposition was predominantly associated with advance of the local ice sheet margin. Later in glacial intervals, IRD content was generally lower, which may have been linked to colder Antarctic temperatures that restricted icebergs from calving and/or reduced melting during transport. At such times, icebergs may have survived transport to more distal locations at lower latitudes, such as Site TN057-6-PC4 in the southeast Atlantic (Fig. 8B, Teitler et al., 2010). 
Overall, the temporal pattern of IRD MAR at our core sites during the late Quaternary is similar to the Pliocene record at Prydz Bay ODP Site 1165 (Fig. $1 A$ ), in which relatively high IRD MAR also coincided with an advancing and/or advanced LGAISS (Passchier, 2011). However, it contrasts with Pliocene (Patterson et al., 2014) and late Quaternary (Wilson et al., 2018) IRD records from Site U1361 offshore of the Wilkes Subglacial Basin (Fig. 1A). At Site U1361, higher IRD deposition occurred mainly during deglacial periods (Fig. $8 \mathrm{C}$ ), as a consequence of accelerated calving from retreating marine-terminating outlet glaciers, with only minor IRD deposition during ice margin advance (Patterson et al., 2014; Bertram et al., 2018; Wilson et al., 2018). In addition, a long term decline in IRD content over the last $\sim 500 \mathrm{kyr}$ was observed at Site U1361 (Wilson et al., 2018) (Fig. 8C), whereas no long term trend is seen in our IRD records (Figs. 8D-E). The Prydz Bay core sites and Site U1361 are located at similar distances from the EAIS margin and in similar latitudes, and likely experienced similar oceanic forcing, as indicated indirectly by local productivity records (Figs. 8C-E). Therefore, these results highlight regional differences in dynamic iceberg discharge from the EAIS and/or variable local influences of ice shelf processes on IRD input to sediments.

\subsubsection{Retreat and advance of the LGAISS linked to sea-level variability and oceanic forcing}

While the IRD records indicate dynamic behaviour of the LGAISS throughout the last $520 \mathrm{kyr}$, they only reflect transient events of dynamic iceberg discharge from the calving front (e.g. Patterson et al., 2014; Wilson et al., 2018) and provide limited insight into ice dynamics during interglacial periods when IRD fluxes from the LGAISS were generally low. In contrast, the clay mineralogy, plotted as the EM2/(EM1+EM2) ratio (Fig. 11D), shows clear glacial-interglacial variations from which we can further infer retreat and advance of the LGAISS.

Temporal variations in the EM2/(EM1+EM2) ratio (Fig. 11D) correspond closely with changes in global sea level (Fig. 11B) and local productivity (Fig. $11 \mathrm{~F}$ ), indicating retreat of the LGAISS during interglacials and advance during glacials (Fig. 10). During the late Quaternary, glacial-interglacial sea level variations reached up to $\sim 130 \mathrm{~m}$ (Waelbroeck et al., 2002; Spratt and Lisiecki, 2016), predominantly controlled by the Northern Hemisphere ice sheets (Lisiecki and Raymo, 2005). Such in-phase behaviour of the LGAISS and the Northern Hemisphere ice sheets on orbital timescales is consistent with the operation of climatic teleconnections between the southern and northern polar regions (e.g. Naish et al., 2009; Pollard and DeConto, 2009; Clark et al., 2020). Ice sheet models suggest that global sea level change influences the contact between seawater and marine-based Antarctic Ice Sheet margins, with sea level rise increasing the sensitivity of the ice sheet to climate forcing (Tigchelaar et al 2019). Furthermore, the consistency between the 
EM2/(EM1+EM2) record and local productivity changes (Fig. 11F), which reflect sea ice coverage and nutrient supply from upwelling CDW (Wu et al., 2017), suggests that oceanic mechanisms could have provided a direct local forcing that led to interglacial ice loss from the LGAISS.

In particular, retreat of the LGAISS during each deglacial period, as indicated by decreasing EM2/(EM1+EM2) ratios (Fig. 11D), could have arisen from the combined effects of enhanced CDW upwelling and reduced sea ice cover. Enhanced CDW upwelling (Anderson et al., 2009), associated with strengthened or southward-shifted Southern Westerly Winds (Menviel et al., 2018), could have supplied warm deep waters to the continental shelf, inducing basal melting of Antarctic ice shelves and marine-based ice sheet margins (Hillenbrand et al., 2017; Clark et al., 2020). In addition, sea ice retreat would have contributed to the release of deeply-sequestered $\mathrm{CO}_{2}$ from the Southern Ocean (Anderson et al., 2009; Ferrari et al., 2014; Jaccard et al., 2016), leading to global climate warming, which would have been regionally amplified by a reduction in albedo (DeConto et al., 2007; Timmermann et al., 2009). On their own, however, our data cannot fully disentangle the relative influence of sea level change versus ocean forcing mechanisms, and indeed the two may have operated synergistically (Tigchelaar et al 2019).

\subsubsection{Retreat and advance of the LGAISS linked to local insolation}

Considering the detailed structure of the clay mineralogy record within interglacial periods, some discrepancies arise between the EM2/(EM1+EM2) ratio (Fig. 11D) and global mean sea level (Fig. 11B), local productivity (Fig. $11 \mathrm{~F}$ ), and Southern Ocean temperatures (Fig. 11G). For example, the $\mathrm{EM} 2 /(\mathrm{EM} 1+\mathrm{EM} 2)$ ratio displays lower values towards the end of MIS 11 than at the start, lower values during MIS 7.1-7.3 than MIS 7.5, continuously low values during MIS 5, and also low values during MIS 3 that are comparable to full interglacial values. These observations may indicate that other controls, additional to global mean sea level and oceanic forcing, operated to influence retreat of the LGAISS. It is striking that low values of the EM2/(EM1+EM2) ratio mostly occurred when global mean sea level high stands coincided with local summer insolation peaks forced by precession (Fig. 11A). Our data therefore provide the first geological evidence for modulation of late Quaternary EAIS dynamics by local summer insolation, supporting the recent modelling results of Tigchelaar et al. (2018) (Fig. 11C).

It has been well documented that precession-paced local summer insolation played an important role in EAIS evolution during intervals prior to the Quaternary when atmospheric $\mathrm{CO}_{2}$ and global temperatures were higher than today (e.g. Grützner et al., 2003; Patterson et al., 2014). For example, Grützner et al. (2003) showed that local summer insolation controlled the LGAISS dynamics during the late Miocene (7.0-7.5 Ma), while strengthened precession cycles in the IRD record from Site U1361 during the late Pliocene to early Pleistocene (3.5-2.5 Ma) were attributed to local summer insolation 
forcing acting on the EAIS in the Wilkes Subglacial Basin (Patterson et al., 2014).

For the LGAISS, our new records demonstrate that the role of local summer insolation during the late Quaternary was most significant when maximum insolation occurred within interglacial periods (Figs. 11A, 11D). Since local summer insolation determines local annual maximum surface air temperatures (Tigchelaar et al., 2018), we propose that local summer insolation led to additional ice loss from the LGAISS by inducing both atmospheric and oceanic warming. In the case of atmospheric warming, enhanced surface melting and elevated meltwater production may have induced a positive feedback that led to additional basal melting by stratifying the surface waters and warming the sub-surface ocean (Phipps et al., 2016). Since these mechanisms appear to have been effective only when superimposed on a background of sufficiently high global mean sea level and temperatures, our results suggest a threshold in the ability of the EAIS margin to respond to atmospheric forcing under late Quaternary boundary conditions.

\subsubsection{Role of subglacial pinning points}

In addition to various climate forcing factors, ice sheet modelling studies have suggested that bed morphology can also play a significant role in the EAIS evolution (Taylor et al., 2004; Golledge et al., 2017b; Pittard et al., 2017). In particular, subglacial pinning points can affect grounding line migration, leading to the potential for decoupling between ice sheet geometry and the instantaneous climate forcing (McKay et al., 2016; Golledge et al., 2017b; Pittard et al., 2017; Wilson et al., 2018). For example, it was suggested that basal pinning points in the Wilkes Subglacial Basin may have restricted complete collapse and contributed to variable ice margin retreat during interglacial climate warming (Wilson et al., 2018), while the bathymetry played a dominant role in the Holocene retreat of the ice sheet in the western inner shelf of the Ross Sea (McKay et al., 2016). Although the Lambert Graben has a different geometry from the Wilkes Subglacial Basin and the Ross Sea inner shelf, being a thin and elongated graben, our clay mineralogy record contains features that suggest its dynamics may also have been influenced by basal and/or lateral pinning points. Specifically, the effect of pinning points could help to explain differences in the retreat patterns between MIS 11 and MIS 9, as well as the general recurrence of particular EM2/(EM1+EM2) ratios through the record, in particular $0.58,0.38$, and 0.18 (Fig. 11D).

During MIS 11, the EM2/(EM1+EM2) ratios suggest that the LGAISS experienced a two-phase retreat (Fig. 11D), corresponding to two peaks on the summer insolation curve (Fig. 11A). In contrast, during MIS 9, there were also two summer insolation peaks, but the LGAISS only experienced a retreat phase linked to the first insolation peak, while the second insolation peak was associated with a lower plateau on the EM2/(EM1+EM2) record (Fig. 11D). These differences are not readily linked to differences in climate forcing (Fig. 
11), but the $E M 2 /(E M 1+E M 2)$ ratios for each of these time periods occur repeatedly throughout the records. For example, the EM2/(EM1+EM2) values during late MIS $9(0.58)$ are similar to those during MIS 7.5 and in early parts of multiple glacial periods; the values during early MIS $11(0.38)$ are similar to those during MIS 7.1-7.3 and at the core top; and the values during late MIS 11 and early MIS $9(0.18)$ are typical of most of the peak interglacials. Since these recurring positions of the LGAISS are not directly related to the climate forcing (Figs. 11A-B and 11F-H), and do not appear to be replicated in the Wilkes Subglacial Basin (Fig. 11E) or in modelled Antarctic ice volume time series (Fig. $11 C$ ), they may represent pinning points on the bed or margins of the LGAISS.

Considering that the inferred retreat of the LGAISS differed between interglacial periods (Fig. 11D), we suggest that either the pinning points evolved due to glacial erosion by the LGAISS, or that subtle differences in the combinations of climate forcing between interglacials allowed the LGAISS to stabilise at different pinning points. Given the lack of a long-term trend in the $E M 2 /(E M 1+E M 2)$ ratios, and the multiple occasions on which the system returned to particular EM2/(EM1+EM2) ratios (dashed lines in Fig. 11), we consider the latter scenario to be most likely. Retreat beyond each pinning point probably required a threshold to be crossed, which could be achieved by a combination of the timing, magnitude, and mechanisms of climate forcing. As such, our record indicates that both global and regional climate forcing, and local bathymetric features, may combine in a complex manner to determine past and future ice sheet dynamics.

\subsection{Implications of differences between individual glacial and interglacial periods}

Having discussed the range of possible controls on the late Quaternary dynamics of the LGAISS, this final section focuses on specific differences between individual glacial and interglacial periods and their implications.

At the glacial maxima of MIS 12, MIS 10, MIS 8, and MIS 6, the $\mathrm{EM} 2 /(\mathrm{EM} 1+\mathrm{EM} 2)$ ratio consistently reached high values of around 0.9 (Fig. 11D), indicating that the LGAISS advanced to a uniform northern limit, presumably constrained by the bathymetry of the continental shelf (Fig. 1A). This observation is consistent with time series of modelled Antarctic ice volume (Fig. 11C), and with the lack of long term trends in our IRD records (Fig. 8D-E). In contrast, during MIS 4 and MIS 2, the EM2/(EM1+EM2) ratio did not reach such high values (Fig. 11D), which suggests a more restricted advance of the LGAISS. This inference is consistent with independent evidence that the LGAISS did not advance to the outer shelf of Prydz Bay during the Last Glacial Maximum (Domack et al., 1998; O'Brien et al., 2007), and provides confidence in the ability of our approach to resolve past changes in the advance and retreat of the LGAISS. The Site U1361 sediment provenance record (Fig. 11E; Wilson et al., 2018) could also be interpreted to show more limited ice sheet advance in the Wilkes Subglacial Basin during MIS 4 and MIS 2 than during 
previous glacial intervals, whereas the total Antarctic Ice Sheet volume was probably similar to earlier glacials (Fig. 11C). We therefore suggest that the EAIS and the West Antarctic Ice Sheet may have responded differently to the climate forcing during these periods. Restricted glacial expansion of the EAIS could reflect a combination of its slow growth and the short duration of the global sea level low stand during these periods (Domack et al., 1998), but it may also have been influenced by local effects such as sediment accumulation near the grounding line (Wilson et al., 2018).

Another important observation is that most peak interglacial periods of the late Pleistocene (except MIS 7) had slightly lower EM2/(EM1+EM2) ratios than the Holocene core top (Fig 11D), suggesting a more retreated LGAISS than today. This observation is consistent with the behaviour of the EAIS in the Wilkes Subglacial Basin inferred from Site U1361 (Fig. 11E; Wilson et al., 2018), and with evidence for warmer Antarctic (Fig. 11H; EPICA Community Members, 2004) and Southern Ocean temperatures (Fig. 11G; Martínez-Garcia et al., 2009) at these times compared to the pre-industrial Holocene. Hence, our new record adds to a growing body of evidence supporting a link between regional warming and EAIS margin retreat (Passchier, 2011; Cook et al., 2013; Mengel and Levermann, 2014; DeConto and Pollard, 2016; Wilson et al., 2018; Blackburn et al., 2020).

The highest interglacial EM2/(EM1+EM2) values occurred during MIS 7 (Fig. 11D), indicating a more muted response of the LGAISS during this recent interglacial, as also inferred for the ice sheet in the Wilkes Subglacial Basin (Fig. 11E; Wilson et al., 2018). We therefore suggest that less extensive retreat of the EAIS margins may have been a general feature of MIS 7, potentially linked to the short duration of Antarctic warmth during this interglacial (Fig. $11 \mathrm{H})$. A muted EAIS response during MIS 7 appears to be in better agreement with the recent ice sheet modelling study of Sutter et al. (2019) than with some previous studies (Fig. 11C; Pollard and DeConto, 2009; Tigchelaar et al., 2018).

The response of the LGAISS to moderately warm climates can also be explored during MIS 3, when the EM2/(EM1+EM2) values were actually lower than during MIS 7 and similar to Holocene values (Fig. 11D). The implied retreat of the LGAISS at this time seems hard to explain given the lower local productivity (Fig. 11F) and cooler Antarctic temperatures (Figs. 11G-H) during MIS 3 than MIS 7, and is inconsistent with modelled changes in total Antarctic Ice Sheet volume (Fig. 11C). However, a retreated state is also supported by the lack of iron-stained quartz in the IRD fraction during this period (Fig. 6D). Recent modelling work suggests that grounding line retreat and decreases in Antarctic Ice Sheet thickness may have occurred during millennial events within MIS 3 (Blasco et al., 2019), while another recent study proposed that global sea levels during MIS 3 may have been 30-40 m higher than previous estimates (Fig. 11B) (Batchelor et al., 2019). In light of evidence that the Northern Hemisphere ice sheets may have been more limited in extent during 
MIS 3 than previously thought (Hughes et al., 2015; Pico et al., 2016; Dalton et al., 2019), and given the strong forcing of global sea level on the Antarctic Ice Sheet (Pollard and DeConto, 2009; Tigchelaar et al., 2018; 2019), modelled Antarctic ice volumes during MIS 3 (Fig. 11C) may have been overestimated. Hence, higher global sea levels during MIS 3 may imply more extensive retreat of the EAIS at this time.

Globally, a range of paleoclimate archives also record values during MIS 3 that are comparable with those during full interglacials, such as the $\mathrm{Zr} / \mathrm{Rb}$ ratio and mean grain size of quartz in Chinese loess (Chen et al., 2006), the aeolian flux to the northwest Pacific Ocean (Hovan et al., 1991), the magnetic susceptibility in Siberian Lake El'gygytgyn (Melles et al., 2012), and the manganese content and foraminiferal abundance in the Arctic Ocean (Xiao et al., 2020). However, records that reflect the dynamic behaviour of the EAIS during MIS 3 are rare. Whether there was a similar retreat of the ice margin in the Wilkes Subglacial Basin at this time is unclear due to age model limitations at Site U1361 (Wilson et al., 2018); the plotted provenance record would suggest no retreat, but comparison to the $\mathrm{Ba} / \mathrm{Al}$ record indicates that the moderate $\mathrm{Nd}$ isotope peak at $\sim 85 \mathrm{ka}$ could potentially fall within MIS 3 (Fig. $11 \mathrm{E})$. Hence, further studies will be required to establish whether retreat during MIS 3 only occurred in Prydz Bay or was a more widespread feature of the EAIS.

Surprisingly, the lowest $\mathrm{EM} 2 /(\mathrm{EM} 1+\mathrm{EM} 2)$ ratios occurred during late MIS 13 (Fig. 11D), which suggests that the most substantial retreat of the LGAISS may have occurred at this time, in contrast to modelled Antarctic ice volume (Fig. 11C). Although the low EM2/(EM1+EM2) values coincide with a local summer insolation peak (Fig. 11A), this period was a luke-warm interglacial (Fig. 11H; EPICA Community Members, 2004) that was characterised by lower global sea levels (Fig. 11B), cooler Southern Ocean sea surface temperatures (Fig. 11G), and lower local productivity (Fig. 11F) than more recent interglacials (e.g. MIS 1, 5, 9, and 11). Records from the Amundsen Sea suggest that the extended duration of warmth during MIS 15-13 may have led to substantial retreat of the West Antarctic Ice Sheet (Hillenbrand et al., 2009), although cycles of glacial advance and retreat in the Ross Sea during MIS 15-13 appear to have been similar to other late Quaternary cycles (McKay et al., 2012). Here we suggest that the extended MIS 15-13 warmth, in combination with local summer insolation forcing, could have led to extreme retreat of the LGAISS during MIS 13, either directly or via dynamic oceanic feedbacks (e.g. Phipps et al., 2016). However, this hypothesis awaits further testing with longer sediment records spanning MIS 15-13, as well as previous luke-warm interglacials, from the EAIS margin.

\section{Summary and conclusions}

In this study, we provide high-resolution IRD and clay mineralogy records 
from two gravity cores retrieved from offshore of Prydz Bay to investigate the dynamics of the LGAISS over the past $520 \mathrm{kyr}$. Major conclusions are drawn as follows:

(1) Iceberg rafted debris (>154 $\mu \mathrm{m}$ coarse fraction) was mainly of local origin and records major advances of the LGAISS during recent glacial periods, while deglacial retreat of the LGAISS is indicated by simultaneously elevated silt/clay ratios and sedimentation rates. Together, these data indicate that the LGAISS showed highly dynamic behaviour throughout the past $520 \mathrm{kyr}$.

(2) Changes in clay mineralogy were also associated with the dynamic behaviour of the LGAISS. On orbital timescales, advance and retreat of the LGAISS occurred in phase with global mean sea level, indicating a temporal link to the waxing and waning of the Northern Hemisphere ice sheets.

(3) The LGAISS was sensitive to a range of oceanic forcing factors throughout the late Quaternary, including ocean temperature, CDW upwelling, and sea ice extent. It may also have responded to peaks in local summer insolation forcing during warm interglacial periods, which hints at a limited additional influence from atmospheric forcing. Our data also supports the idea that pinning points on the basement could play a role in modulating the migration behaviour of the LGAISS.

(4) The LGAISS appears to have retreated most extensively during MIS 13, and only retreated moderately during MIS 7 , which suggests that the duration of warm climate states could be a key factor affecting the dynamics of the EAIS.

\section{Declaration of competing interest}

The authors declare that they have no conflicts of interests to this work.

\section{Acknowledgements}

We thank the $29^{\text {th }}$ and the $30^{\text {th }}$ Chinese Antarctic Expedition cruise members for retrieving the sediments, and are grateful to authors who have provided us with data on request or via online repositories. Thanks also go to Dr. Lingmin Zhang from State Key Laboratory of Marine Geology, Tongji University for her kind technical support with scanning electronic microscope and energy-dispersive spectroscopy analyses. We would particularly like to acknowledge two anonymous reviewers for their detailed and insightful reviews that helped us to significantly improve the final version of this paper. This work was jointly supported by National Natural Science Foundation of China, Postdoctoral Research Foundation of China (Grants No. 41806223, 2018M632158, 41776191 and 41676191), the Ministry of Natural Resources of China and the RFSOCC2020-2022-No.16 \& 17 Project of the National Oceanic Administration's Polar Expedition Office. 


\section{Appendix information. Supplementary data}

Appendix information and supplementary data linked to this article can be found online.

\section{References}

Anderson, R.F., Ali, S., Bradtmiller, L.I., Nielsen, S.H.H., Fleisher, M.Q., Anderson, B.E., Burckle, L.H., 2009. Wind-driven upwelling in the Southern Ocean and the deglacial rise in atmospheric $\mathrm{CO}_{2}$. Science 323, 1443-1448.

Batchelor, C.L., Margold, M., Krapp, M., Murton, D.K., Dalton, A.S., Gibbard, P.L., Stokes, C.R., Murton, J.B., Manica, A., 2019. The configuration of Northern Hemisphere ice sheets through the Quaternary. Nature Communications 10, 3713.

Bakker, A.M.R., Wong, T.E., Ruckert, K.L., Keller, K., 2017. Sea-level projections representing the deeply uncertain contribution of the West Antarctic ice sheet. Scientific Reports 7, 3880.

Bertram, R.A., Wilson, D.J., van de Flierdt, T., McKay, R.M., Patterson, M.O., Jimenez-Espejo, F.J., Escutia, C., Duke, G.C., Taylor-Silva, B.I., Riesselmann, C.R., 2018. Pliocene deglacial event timelines and the biogeochemical response offshore Wilkes Subglacial Basin, East Antarctica. Earth and Planetary Science Letters 494, 109-116.

Bindoff, N.L., Rosenberg, M.A., Warner, M.J., 2000. On the circulation and water masses over the Antarctic continental slope and rise between 80 and $150^{\circ}$ E. Deep Sea Research Part II: Topical Studies in Oceanography 47, 2299-2326.

Blackburn, T., Edwards, G.H., Tulaczyk, S., Scudder, M., Piccione, G., Hallet, B., McLean, N., Zachos, J.C., Cheney, B., Babbe, J.T., 2020. Ice retreat in Wilkes Basin of East Antarctica during a warm interglacial. Nature 583, 554-559.

Blasco, J., Tabone, I., Alvarez-Solas, J., Robinson, A., Montoya, M., 2019. The Antarctic Ice Sheet response to glacial millennial-scale variability. Climate of the Past 15, 121-133.

Boger, S.D., Wilson, C.J.L., Fanning, C.M., 2001. Early Paleozoic tectonism within the East Antarctic craton: The final suture between east and west Gondwana? Geology 29, 463-466.

Borchers, A., Voigt, I., Kuhn, G., Diekmann, B., 2011. Mineralogy of glaciomarine sediments from the Prydz Bay-Kerguelen region: relation to modern depositional environments. Antarctic Science 23, 164-179.

Borchers, A., Dietze, E., Kuhn, G., Esper, O., Voigt, I., Hartmann, K., Diekmann, B., 2016. Holocene ice dynamics and bottom-water formation associated with Cape Darnley polynya activity recorded in Burton Basin, East Antarctica. Marine Geophysical Research 37, 49-70.

Chamley, H., 1989. Clay Sedimentology. Springer, Berlin. 623 pp. 
Chen, J., Chen, Y., Liu, L., Ji, J., Balsam, W., Sun, Y., Lu, H., 2006. Zr/Rb ratio in the Chinese loess sequences and its implication for changes in the East Asian winter monsoon strength. Geochimica et Cosmochimica Acta 70, 1471-1482.

Clark, P.U., He, F., Golledge, N.R., Mitrovica, J.X., Dutton, A., Hoffman, J.S., Dendy, S., 2020. Oceanic forcing of penultimate deglacial and last interglacial sea-level rise. Nature 577, 660-664.

Cook, C., van de Flierdt, T., Williams, T., Hemming, S.R., Iwai, M., Kobayashi, M., Jiménez-Espejo, F.J., Escutia, C., González, J.J., Khim, B.-K., McKay, R.M., Passchier, S., Bohaty, S.M., Riesselman, C.R., Tauxe, L., Sugisaki, S., Galindo, A.L., Patterson, M.O., Sangiorgi, F., Pierce, E.L., Brinkhuis, H., IODP Expedition 318 Scientists, 2013. Dynamic behaviour of the East Antarctic ice sheet during Pliocene warmth. Nature Geosciences 6, 765-769.

Cook, C.P., Hill, D.J., van de Flierdt, T., Williams, T., Hemming, S.R., Dolan, A.M., Pierce, E.L., Escutia, C., Harwood, D., Cortese, G., Gonzales, J.J., 2014. Sea surface temperature control on the distribution of far-traveled Southern Ocean ice-rafted detritus during the Pliocene. Paleoceanography 29, 533-548.

Cowan, E.A., Hillenbrand, C.-D., Hassler, L.E., Ake, M.T., 2008. Coarse-grained terrigenous sediment deposition on continental rise drifts: $A$ record of Plio-Pleistocene glaciation on the Antarctic Peninsula. Palaeogeography, Palaeoclimatology, Palaeoecology 265, 275-291.

Dalton, A.S., Finkelstein, S.A., Forman, S.L., Barnett, P.J., Pico, T., Mitrovica, J.X., 2019. Was the Laurentide Ice Sheet significantly reduced during Marine Isotope Stage 3? Geology 47, 111-114.

Death, R., Siegert, M.J., Bigg, G.R., Wadley, M.R., 2006. Modelling iceberg trajectories, sedimentation rates and meltwater input to the ocean from the Eurasian Ice Sheet at the Last Glacial Maximum. Palaeogeography, Palaeoclimatology, Palaeoecology 236, 135-150.

DeConto, R., Pollard, D., Harwood, D., 2007. Sea ice feedback and Cenozoic evolution of Antarctic climate and ice sheet. Paleoceanography 22, PA3214.

DeConto, R.M., Pollard, D., 2016. Contribution of Antarctica to past and future sea-level rise. Nature 531, 591-597.

Depoorter, M.A., Bamber, J.L., Griggs, J.A., Lenaerts, J.T.M., Ligtenberg, S.R.M., van den Broeke, M.R., Moholdt, G., 2013. Calving fluxes and basal melt rates of Antarctic ice shelves. Nature 502, 89-92.

Dietze, E., Hartmann, K., Diekmann, B., IJmker, J., Lehmkuhl, F., Opitz, S., Stauch, G., Wünnemann, B., Borchers, A., 2012. An end-member algorithm for deciphering modern detrital processes from lake sediments of Lake Donggi Cona, NE Tibetan Plateau, China. Sedimentary Geology 243, 169-180.

Domack, E., Leventer, A., Dunbar, R., Taylor, F., Brachfeld, S., Sjunneskog, C., 
2001. Chronology of the Palmer Deep site, Antarctic Peninsula: a Holocene palaeoenvironmental reference for the circum-Antarctic. The Holocene 11, 1-9.

Domack, E., O'Brien, P., Harris, P., Taylor, F., Quilty, P.G., De Santis, L., Raker, B., 1998. Late Quaternary sediment facies in Prydz Bay, East Antarctica and their relationship to glacial advance onto the continental shelf. Antarctic Science 10, 236-246.

Edwards, T.L., Brandon, M.A., Durand, G., Edwards, N.R., Golledge, N.R., Holden, P.B., Nias, I.J., Payne, A.J., Ritz, C., Wernecke, A., 2019. Revisiting Antarctic ice loss due to marine ice-cliff instability. Nature 566, 58-64.

Ehrmann, W., 1991. Implications of sediment composition on the southern Kerguelen Plateau for paleoclimate and depositional environment. In: Barron, J., Larsen, B., et al. (eds.), Proc. ODP, Sci. Results, College Station, TX (Ocean Drilling Program), 119, 185-210.

Ehrmann, W., Bloemendal, J., Hambrey, M.J., McKelvey, B., Whitehead, J., 2003. Variations in the composition of the clay fraction of the Cenozoic Pagodroma Group, East Antarctica: implications for determining provenance. Sedimentary Geology 161, 131-152.

EPICA Community Members, 2004. Eight glacial cycles from an Antarctic ice core. Nature 429, 623-628.

Ferrari, R., Jansen, M.F., Adkins, J.F., Burke, A., Stewart, A.L., Thompson, A.F., 2014. Antarctic sea ice control on ocean circulation in present and glacial climates. Proceedings of the National Academy of Sciences of the United States of America 111, 8753-8758.

Folk, R.L., Ward, W.C., 1957. Brazos River bar: a study in the significance of grain size parameters. Journal of Sedimentary Research 27, 3-26.

Fretwell, P., Pritchard, H.D., Vaughan, D.G., Bamber, J.L., Barrand, N.E., Bell, R., Bianchi, C., Bingham, R.G., Blankenship, D.D., Casassa, G., et al. 2013. Bedmap2: improved ice bed, surface and thickness datasets for Antarctica. The Cryosphere 7, 375-393.

Golledge, N.R., Kowalewski, D.E., Naish, T.R., Levy, R.H., Fogwill, C.J., Gasson, E.G.W., 2015. The multi-millennial Antarctic commitment to future sea-level rise. Nature 526, 421-425.

Golledge, N.R., Levy, R.H., McKay, R.M., Naish, T.R., 2017a. East Antarctic ice sheet most vulnerable to Weddell Sea warming. Geophysical Research Letters 44, 2343-2351.

Golledge, N.R., Thomas, Z.A., Levy, R.H., Gasson, E.G.W., Naish, T.R., McKay, R.M., Kowalewski, D.E., Fogwill, C.J., 2017b. Antarctic climate and ice-sheet configuration during the early Pliocene interglacial at 4.23 Ma. Climate of the Past 13, 959-975.

Grützner, J., Rebesco, M.A., Cooper, A.K., Forsberg, C.F., Kryc, K.A., Wefer, G., 2003. Evidence for orbitally controlled size variations of the East Antarctic Ice Sheet during the late Miocene. Geology 31, 777-780. 
Hambrey, M.J., Ehrmann, W., Larsen, B., 1991. Cenozoic glacial record of the Prydz Bay continental shelf, East Antarctica. In: Barron, J., Larsen, B., et al. (eds.), Proc. ODP, Sci. Results, College Station, TX (Ocean Drilling Program), 119, 77-132.

Hambrey, M.J., McKelvey, B., 2000. Major Neogene fluctuations of the East Antarctic ice sheet: Stratigraphic evidence from the Lambert Glacier region. Geology 28, 887-890.

Hannah, M.J., 2006. The palynology of ODP site 1165, Prydz Bay, East Antarctica: A record of Miocene glacial advance and retreat. Palaeogeography, Palaeoclimatology, Palaeoecology 231, 120-133.

Hillenbrand, C.-D., Grobe, H., Diekmann, B., Kuhn, G., Fütterer, D.K., 2003. Distribution of clay minerals and proxies for productivity in surface sediments of the Bellingshausen and Amundsen seas (West Antarctica) Relation to modern environmental conditions. Marine Geology 193, 253-271.

Hillenbrand, C.-D., Smith, J.A., Hodell, D.A., Greaves, M., Poole, C.R., Kender, S., Williams, M., Andersen, T.J., Jernas, P.E., Elderfield, H., Klages, J.P., Roberts, S.J., Gohl, K., Larter, R.D., Kuhn, G., 2017. West Antarctic Ice Sheet retreat driven by Holocene warm water incursions. Nature 547, 43-48.

Hillenbrand, C.-D., Kuhn, G., Frederichs, T., 2009. Record of a Mid-Pleistocene depositional anomaly in West Antarctic continental margin sediments: an indicator for ice-sheet collapse? Quaternary Science Reviews 28, 1147-1159.

Holtzapffel, T., 1985. Les Minéraux Argileux: Préparation, Analyse Diffractométrique et Determination. Societe Geologique du Nord, 12.

Hovan, S.A., Rea, D.K., Pisias, N.G., 1991. Late Pleistocene continental climate and oceanic variability recorded in northwest Pacific sediments. Paleoceanography 6, 349-370.

Hughes, A.L.C., Gyllencreutz, R., Lohne, Ø.S., Mangerud, J., Svendsen, J.I., 2015. The last Eurasian ice sheets - a chronological database and time-slice reconstruction, DATED-1. Boreas 45, 1-45.

Jaccard, S.L., Galbraith, E.D., Martínez-García, A., Anderson, R.F., 2016. Covariation of deep Southern Ocean oxygenation and atmospheric $\mathrm{CO}_{2}$ through the last ice age. Nature 530, 207-210.

Joseph, L.H., Rea, D.K., van der Pluijm, B.A., Gleason, J.D., 2002. Antarctic environmental variability since the late Miocene: ODP Site 745, the East Kerguelen sediment drift. Earth and Planetary Science Letters 201, 127-142.

Junttila, J., Ruikka, M., Strand, K., 2005. Clay-mineral assemblages in high-resolution Plio-Pleistocene interval at ODP Site 1165, Prydz Bay, Antarctica. Global and Planetary Change 45, 151-163.

Laskar, J., Robutel, P., Joutel, F., Gastineau, M., Correia, A.C.M., Levrard, B., 2004. A long-term numerical solution for the insolation quantities of the 
Earth. Astronomy \& Astrophysics 428, 261-285.

Leitchenkov, G., Stagg, H., Gandjukhin, V., Cooper, A.K., Tanahashi, M., O'Brien, P., 1994. Cenozoic seismic stratigraphy of Prydz Bay (Antarctica). Terra Antartica 1, 395-397.

Lisiecki, L.E., Lisiecki, P.A., 2002. Application of dynamic programming to the correlation of paleoclimate records. Paleoceanography 17, 1049.

Lisiecki, L.E., Raymo, M.E., 2005. A Pliocene-Pleistocene stack of 57 globally distributed benthic $\delta^{18} \mathrm{O}$ records. Paleoceanography 20. PA1003

Liu, X.C., Jahn, B.M., Zhao, Y., Li, M., Li, H.M., Liu, X.H., 2006. Late Pan-African granitoids from the Grove Mountains, East Antarctica: Age, origin and tectonic implications. Precambrian Research 145, 131-154.

Liu, Z., Trentesaux, A., Clemens, S.C., Colin, C., Wang, P., Huang, B., Boulay, S., 2003. Clay mineral assemblages in the northern South China Sea: implications for East Asian monsoon evolution over the past 2 million years. Marine Geology 201, 133-146.

Liu, Z., Zhao, Y., Li, J., Colin, C., 2007. Late Quaternary clay minerals off Middle Vietnam in the western South China Sea: Implications for source analysis and East Asian monsoon evolution. Science in China Series D: Earth Sciences 50, 1674-1684.

Martínez-García, A., Rosell-Melé, A., Geibert, W., Gersonde, R., Masqué, P., Gaspari, V., Barbante, C., 2009. Links between iron supply, marine productivity, sea surface temperature, and $\mathrm{CO}_{2}$ over the last $1.1 \mathrm{Ma}$. Paleoceanography 24, PA1207.

Mathiot, P., Goosse, H., Fichefet, T., Barnier, B., Gallée, H., 2011. Modelling the seasonal variability of the Antarctic Slope Current. Ocean Science 7, 455-470.

McCave, I.N., Andrews, J.T., 2019. Distinguishing current effects in sediments delivered to the ocean by ice. I. Principles, methods and examples. Quaternary Science Reviews 212, 92-107.

McKay, R., Golledge, N.R., Maas, S., Naish, T., Levy, R., Dunbar, G., Kuhn, G., 2016. Antarctic marine ice-sheet retreat in the Ross Sea during the early Holocene. Geology 44, 7-10.

McKay, R., Naish, T., Powell, R., Barrett, P., Scherer, R., Talarico, F., Kyle, P., Monien, D., Kuhn, G., Jackolski, C., Williams, T., 2012. Pleistocene variability of Antarctic Ice Sheet extent in the Ross Embayment. Quaternary Science Reviews 34, 93-112.

Melles, M., Brigham-Grette, J., Minyuk, P.S., Nowaczyk, N.R., Wennrich, V., DeConto, R.M., Anderson, P.M., Andreev, A.A., Coletti, A., Cook, T.L., Haltia-Hovi, E., Kukkonen, M., Lozhkin, A.V., Rosen, P., Tarasov, P., Vogel, H., Wagner, B., 2012. 2.8 million years of Arctic climate change from Lake El'gygytgyn, NE Russia. Science 337, 315-320.

Mengel, M., Levermann, A., 2014. Ice plug prevents irreversible discharge from East Antarctica. Nature Climate Change 4, 451-455.

Menviel, L., Spence, P., Yu, J., Chamberlain, M.A., Matear, R.J., Meissner, K.J., 
England, M.H., 2018. Southern Hemisphere westerlies as a driver of the early deglacial atmospheric $\mathrm{CO}_{2}$ rise. Nature Communications 9, 2503.

Mikhalsky, E.V., Sheraton, J.W., Laiba, A.A., Tingey, R.J., Thost, D.E., Kamenev, E.N., Fedorov, L.V., 2001. Geology of the Prince Charles Mountains. AGSO-Geosci. Aust. Bull. 247, 210 pp.

Morlighem, M., Rignot, E., Binder, T., Blankenship, D., Drews, R., Eagles, G., Eisen, O., Ferraccioli, F., Forsberg, R., Fretwell, P., et al. 2020. Deep glacial troughs and stabilizing ridges unveiled beneath the margins of the Antarctic ice sheet. Nature Geoscience 13, 132-137.

Nagao, S., Nakashima, S., 1992. The factors controlling vertical color variations of North Atlantic Madeira Abyssal Plain sediments. Marine Geology 109, 83-94.

Naish, T., Powell, R., Levy, R., Wilson, G., Scherer, R., Talarico, F., Krissek, L., Niessen, F., Pompilio, M., Wilson, T., Carter, L., DeConto, R., Huybers, P., McKay, R., Pollard, D., Ross, J., Winter, D., Barrett, P., Browne, G., Cody, R., Cowan, E., Crampton, J., Dunbar, G., Dunbar, N., Florindo, F., Gebhardt, C., Graham, I., Hannah, M., Hansaraj, D., Harwood, D., Helling, D., Henrys, S., Hinnov, L., Kuhn, G., Kyle, P., Laufer, A., Maffioli, P., Magens, D., Mandernack, K., McIntosh, W., Millan, C., Morin, R., Ohneiser, C., Paulsen, T., Persico, D., Raine, I., Reed, J., Riesselman, C., Sagnotti, L., Schmitt, D., Sjunneskog, C., Strong, P., Taviani, M., Vogel, S., Wilch, T., Williams, T., 2009. Obliquity-paced Pliocene West Antarctic ice sheet oscillations. Nature 458, 322-328.

Naish, T.R., Woolfe, K.J., Barrett, P.J., Wilson, G.S., Atkins, C., Bohaty, S.M., Bucker, C.J., Claps, M., Davey, F.J., Dunbar, G.B., Dunn, A.G., Fielding, C.R., Florindo, F., Hannah, M.J., Harwood, D.M., Henrys, S.A., Krissek, L.A., Lavelle, M., van der Meer, J., Mclntosh, W.C., Niessen, F., Passchier, S., Powell, R.D., Roberts, A.P., Sagnotti, L., Scherer, R.P., Strong, C.P., Talarico, F., Verosub, K.L., Villa, G., Watkins, D.K., Webb, P.-N., Wonik, T., 2001. Orbitally induced oscillations in the East Antarctic ice sheet at the Oligocene/Miocene boundary. Nature 413, 719-723.

Nunes Vaz, R.A., Lennon, G.W., 1996. Physical oceanography of the Prydz Bay region of Antarctic waters. Deep Sea Research Part I: Oceanographic Research Papers 43, 603-641.

O'Brien, P.E., Goodwin, I., Forsberg, C.F., Cooper, A.K., Whitehead, J., 2007. Late Neogene ice drainage changes in Prydz Bay, East Antarctica and the interaction of Antarctic ice sheet evolution and climate. Palaeogeography, Palaeoclimatology, Palaeoecology 245, 390-410.

Ó Cofaigh, C., Dowdeswell, J.A., Pudsey, C., 2001. Late Quaternary iceberg rafting along the Antarctic Peninsula continental rise and in the Weddell and Scotia Seas. Quaternary Research 56, 308-321.

Passchier, S., 2011. Linkages between East Antarctic Ice Sheet extent and Southern Ocean temperatures based on a Pliocene high-resolution record of ice-rafted debris off Prydz Bay, East Antarctica. Paleoceanography 26, 
PA4204.

Passchier, S., O’Brien, P.E., Damuth, J.E., Januszczak, N., Handwerger, D.A., Whitehead, J.M., 2003. Pliocene-Pleistocene glaciomarine sedimentation in eastern Prydz Bay and development of the Prydz trough-mouth fan, ODP Sites 1166 and 1167, East Antarctica. Marine Geology 199, 279-305.

Paterson, G.A., Heslop, D., 2015. New methods for unmixing sediment grain size data. Geochemistry, Geophysics, Geosystems 16, 4494-4506.

Patterson, M.O., McKay, R., Naish, T., Escutia, C., Jimenez-Espejo, F.J., Raymo, M.E., Meyers, S.R., Tauxe, L., Brinkhuis, H., IODP Expedition Scientists, 2014. Orbital forcing of the East Antarctic ice sheet during the Pliocene and Early Pleistocene. Nature Geoscience 7, 841-847.

Petschick, R., 2000. MacDiff 4.2.2. available: http://servermac.geologie.un-frankfurt.de/Rainer.html.

Petschick, R., Kuhn, G., Gingele, F., 1996. Clay mineral distribution in surface sediments of the South Atlantic: sources, transport, and relation to oceanography. Marine Geology 130, 203-229.

Phipps, S., Fogwill, C., Turney, C., 2016.. Impacts of marine instability across the East Antarctic Ice Sheet on Southern Ocean dynamics. The Cryosphere, 10, 2317-2328.

Pico, T., Mitrovica, J.X., Ferrier, K.L., Braun, J., 2016. Global ice volume during MIS 3 inferred from a sea-level analysis of sedimentary core records in the Yellow River Delta. Quaternary Science Reviews 152, 72-79.

Pittard, M.L., Galton-Fenzi, B.K., Watson, C.S., Roberts, J.L., 2017. Future sea level change from Antarctica's Lambert-Amery glacial system. Geophysical Research Letters, 44, 7347-7355.

Pollard, D., DeConto, R.M., 2009. Modelling West Antarctic ice sheet growth and collapse through the past five million years. Nature 458, 329-332.

Prins, M.A., Bouwer, L.M., Beets, C.J., Troelstra, S.R., Weltje, G.J., Kruk, R.W., Kuijpers, A., Vroon, P.Z., 2002. Ocean circulation and iceberg discharge in the glacial North Atlantic: Inferences from unmixing of sediment size distributions. Geology 30, 555-558.

Pugh, R.S., McCave, I.N., Hillenbrand, C.-D., Kuhn, G., 2009. Circum-Antarctic age modelling of Quaternary marine cores under the Antarctic Circumpolar Current: Ice-core dust-magnetic correlation. Earth and Planetary Science Letters 284, 113-123.

Reimer, P.J., Bard, E., Bayliss, A., Beck, J.W., Blackwell, P.G., Bronk Ramsey, C., Buck, C.E., Cheng, H., Edwards, R.L., Friedrich, M., 2013. IntCal13 and Marine13 radiocarbon age calibration curves $0-50,000$ years cal BP. Radiocarbon 55, 1869-1887.

Richter, T. O., van der Gaast, S. Koster, B., Vaars, A., Gieles, R., de Stigter, H.C., de Haas, H., van Weering, T.C.E., 2006, The Avaatech XRF Core Scanner: Technical description and applications to NE Atlantic sediments, Geol. Soc. Spec. Publ. 267, 39-50.

Rignot, E., Mouginot, J., Scheuchl, B., van den Broeke, M., van Wessem, M.J., 
Morlighem, M., 2019. Four decades of Antarctic Ice Sheet mass balance from 1979-2017. Proceedings of the National Academy of Sciences 116, 1095-1103.

Roy, M., van de Flierdt, T., Hemming, S.R., Goldstein, S.L., 2007. ${ }^{40} \mathrm{Ar} /{ }^{39} \mathrm{Ar}$ ages of hornblende grains and bulk $\mathrm{Sm} / \mathrm{Nd}$ isotopes of circum-Antarctic glacio-marine sediments: implications for sediment provenance in the southern ocean. Chemical Geology 244, 507-519.

Scherer, R., DeConto, R., Pollard, D., Alley, R., 2016. Windblown Pliocene diatoms and East Antarctic Ice Sheet retreat. Nature Communications 7, 12957.

Schoof, C., 2007. Ice sheet grounding line dynamics: Steady states, stability, and hysteresis. Journal of Geophysical Research: Earth Surface 112. F03S28

Seidel, M., Hlawitschka, M., 2015. An R-based function for modeling of end member compositions. Mathematical Geosciences 47, 995-1007.

Shipboard Scientific Party, 2001. Leg 188 summary: Prydz Bay-Cooperation Sea, Antarctica, in: O'Brien, P.E., Cooper, A.K., Richter, C. et al. (Eds.), Proc. ODP. Init. Rep. 188, 1-65.

Simões Pereira, P., van de Flierdt, T., Hemming, S.R., Frederichs, T., Hammond, S.J., Brachfeld, S., Doherty, C., Kuhn, G., Smith, J.A., Klages, J.P., Hillenbrand, C.-D., 2020. The geochemical and mineralogical fingerprint of West Antarctica's weak underbelly: Pine Island and Thwaites glaciers. Chemical Geology 550, 119649.

Smith, J.A., Graham, A.G.C., Post, A.L., Hillenbrand, C.-D., Bart, P.J., Powell, R.D., 2019. The marine geological imprint of Antarctic ice shelves. Nature Communications 10, 5635.

Spratt, R.M., Lisiecki, L.E., 2016. A Late Pleistocene sea level stack. Climate of the Past. 12, 1079-1092.

Stuiver, M., Reimer, P.J., 1993. Extended ${ }^{14} \mathrm{C}$ data base and revised CALIB 3.0 ${ }^{14} \mathrm{C}$ age calibration program. $35,215-230$.

Stuut, J.B.W., Temmesfeld, F., De Deckker, P., 2014. A 550 ka record of aeolian activity near North West Cape, Australia: inferences from grain-size distributions and bulk chemistry of SE Indian Ocean deep-sea sediments. Quaternary Science Reviews 83, 83-94.

Sutter, J., Fischer, H., Grosfeld, K., Karlsson, N.B., Kleiner, T., Van Liefferinge, B., Eisen, O., 2019. Modelling the Antarctic Ice Sheet across the mid-Pleistocene transition - implications for Oldest Ice. The Cryosphere 13, 2023-2041.

Tang, Z., Shi, X., Zhang, X., Chen, Z., Chen, M.-T., Wang, X., Wang, H., Liu, H., Lohmann, G., Li, P., Ge, S., Huang, Y., 2016. Deglacial biogenic opal peaks revealing enhanced Southern Ocean upwelling during the last $513 \mathrm{ka}$. Quaternary International 425, 445-452.

Taylor, J., Siegert, M.J., Payne, A.J., Hambrey, M.J., O'Brien, P.E., Cooper, A.K., Leitchenkov, G., 2004. Topographic controls on post-Oligocene 
changes in ice-sheet dynamics, Prydz Bay region, East Antarctica. Geology 32, 197-200.

Teitler, L., Warnke, D.A., Venz, K.A., Hodell, D.A., Becquey, S., Gersonde, R., Teitler, W., 2010. Determination of Antarctic Ice Sheet stability over the last $\sim 500$ ka through a study of iceberg-rafted debris. Paleoceanography 25 , PA1202.

Theissen, K.M., Dunbar, R.B., Cooper, A.K., Mucciarone, D.A., Hoffmann, D., 2003. The Pleistocene evolution of the East Antarctic Ice Sheet in the Prydz Bay region: stable isotopic evidence from ODP Site 1167. Global and Planetary Change 39, 227-256.

Tigchelaar, M., Timmermann, A., Friedrich, T., Heinemann, M., Pollard, D., 2019. Nonlinear response of the Antarctic Ice Sheet to late Quaternary sea level and climate forcing. The Cryosphere 13, 2615-2631.

Tigchelaar, M., Timmermann, A., Pollard, D., Friedrich, T., Heinemann, M., 2018. Local insolation changes enhance Antarctic interglacials: Insights from an 800,000-year ice sheet simulation with transient climate forcing. Earth and Planetary Science Letters 495, 69-78.

Timmermann, A., Timm, O., Stott, L., Menviel, L., 2009. The roles of $\mathrm{CO}_{2}$ and orbital forcing in driving Southern Hemispheric temperature variations during the last 21000 Yr. Journal of Climate 22, 1626-1640.

Tingey, R.J., 1991. The regional geology of Archean and Proterozoic rocks in Antarctica. In: Tingey, R.J. (Ed.), The Geology of Antarctica. Clarendon Press, Oxford, 1-73.

Trail, D.S., McLeod, I.R., 1969. Geology of the Lambert Glacier region. In: Craddock, C. (Ed.), Geologic Maps of Antarctica. Am. Geogr. Soc., Antarctic Map Folio Ser. Folio 12, Plate XI.

Van Leeuwen, A.T.D.V., Morrissey, L.J., Kelsey D.E., Raimondo, T. 2019. Recognition of Pan-African-aged metamorphism in the Fisher Terrane, central Prince Charles Mountains, East Antarctica. Journal of the Geological Society 176, 785-798.

Waelbroeck, C., Labeyrie, L., Michel, E., Duplessy, J.C., McManus, J.F., Lambeck, K., Balbon, E., Labracherie, M., 2002. Sea-level and deep water temperature changes derived from benthic foraminifera isotopic records. Quaternary Science Reviews 21, 295-305.

Wang, R., Xiao, W., März, C., Li, Q., 2013. Late Quaternary paleoenvironmental changes revealed by multi-proxy records from the Chukchi Abyssal Plain, western Arctic Ocean. Global and Planetary Change 108, 100-118.

Webb, J.A., Fielding, C.R., 1993. Revised stratigraphical nomenclature for the Permo-Triassic Flagstone Bench Formation, northern Prince Charles Mountains, East Antarctica. Antarctic Science 5, 409-410.

Weber, M.E., Clark, P.U., Kuhn, G., Timmermann, A., Sprenk, D., Gladstone, R., Zhang, X., Lohmann, G., Menviel, L., Chikamoto, M.O., Friedrich, T., Ohlwein, C., 2014. Millennial-scale variability in Antarctic ice-sheet 
discharge during the last deglaciation. Nature 510, 134-138.

Weber, M.E., Kuhn, G., Sprenk, D., Rolf, C., Ohlwein, C., Ricken, W., 2012. Dust transport from Patagonia to Antarctica - A new stratigraphic approach from the Scotia Sea and its implications for the last glacial cycle. Quaternary Science Reviews 36, 177-188.

Weber, M.E., Niessen, F., Kuhn, G., Wiedicke, M., 1997. Calibration and application of marine sedimentary physical properties using a multi-sensor core logger. Marine Geology 136, 151-172.

Weltje, G.J., 1997. End-member modeling of compositional data: numerical-statistical algorithms for solving the explicit mixing problem. Mathematical Geology 29, 503-549.

Whitehead, J., McKelvey, B., 2001. The stratigraphy of the Pliocene-lower Pleistocene Bardin Bluffs Formation, Amery Oasis, northern Prince Charles Mountains, Antarctica. Antarctic Science 13, 79-86.

Williams, T., van de Flierdt, T., Hemming, S.R., Chung, E., Roy, M., Goldstein, S.L., 2010. Evidence for iceberg armadas from East Antarctica in the Southern Ocean during the late Miocene and early Pliocene. Earth and Planetary Science Letters 290, 351-361.

Wilson, D.J., Bertram, R.A., Needham, E.F., van de Flierdt, T., Welsh, K.J., McKay, R.M., Mazumder, A., Riesselman, C.R., Jimenez-Espejo, F.J., Escutia, C., 2018. Ice loss from the East Antarctic Ice Sheet during late Pleistocene interglacials. Nature 561, 383-386.

Wilson, T.J., Grunow, A.M., Hanson, R.E., 1997. Gondwana assembly: The view from Southern Africa and East Gondwana. Journal of Geodynamics 23, 263-286.

Wu, L., Wang, R., Xiao, W., Ge, S., Chen, Z., Krijgsman, W., 2017. Productivity-climate coupling recorded in Pleistocene sediments off Prydz Bay (East Antarctica). Palaeogeography, Palaeoclimatology, Palaeoecology 485, 260-270.

Wu, L., Wang, R., Krijgsman, W., Chen, Z., Xiao, W., Ge, S., Wu, J., 2019. Deciphering color reflectance data of a 520-kyr sediment core from the Southern Ocean: Method application and paleoenvironmental implications. Geochemistry, Geophysics, Geosystems 20, 2808-2826.

Wu, L., Wang, R., Xiao, W., Krijgsman, W., Li, Q., Ge, S., Ma, T., 2018. Late Quaternary deep stratification-climate coupling in the Southern Ocean: Implications for changes in abyssal carbon storage. Geochemistry, Geophysics, Geosystems 19, 379-395.

Wu, L., Wilson, D.J., Wang, R., Yin, X., Chen, Z., Xiao, W., Huang, M., 2020. Evaluating $\mathrm{Zr} / \mathrm{Rb}$ ratio from $\mathrm{XRF}$ scanning as an indicator of grain-size variations of glaciomarine sediments in the Southern Ocean. Geochemistry, Geophysics, Geosystems 21, 10.1029/2020GC009350.

Xiao, W., Frederichs, T., Gersonde, R., Kuhn, G., Esper, O., Zhang, X., 2016. Constraining the dating of late Quaternary marine sediment records from the Scotia Sea (Southern Ocean). Quaternary Geochronology 31, 97-118. 
Xiao, W., Polyak, L., Wang, R., Löwemark, L., Mei, J., You, D., Wang, W., Wu, L., Jin, X., 2020. Middle to Late Pleistocene Arctic paleoceanographic changes based on sedimentary records from Mendeleev Ridge and Makarov Basin. Quaternary Science Reviews 228, 106105.

Yabuki, T., Suga, T., Hanawa, K., Matsuoka, K., Kiwada, H., Watanabe, T., 2006. Possible source of the Antarctic Bottom Water in the Prydz Bay region. Journal of Oceanography 62, 649-655.

Yu, S.Y., Colman, S.M., Li, L., 2016. BEMMA: A hierarchical Bayesian End-Member Modeling Analysis of sediment grain-size distributions. Mathematical Geosciences 48, 723-741. 


\section{Figures}

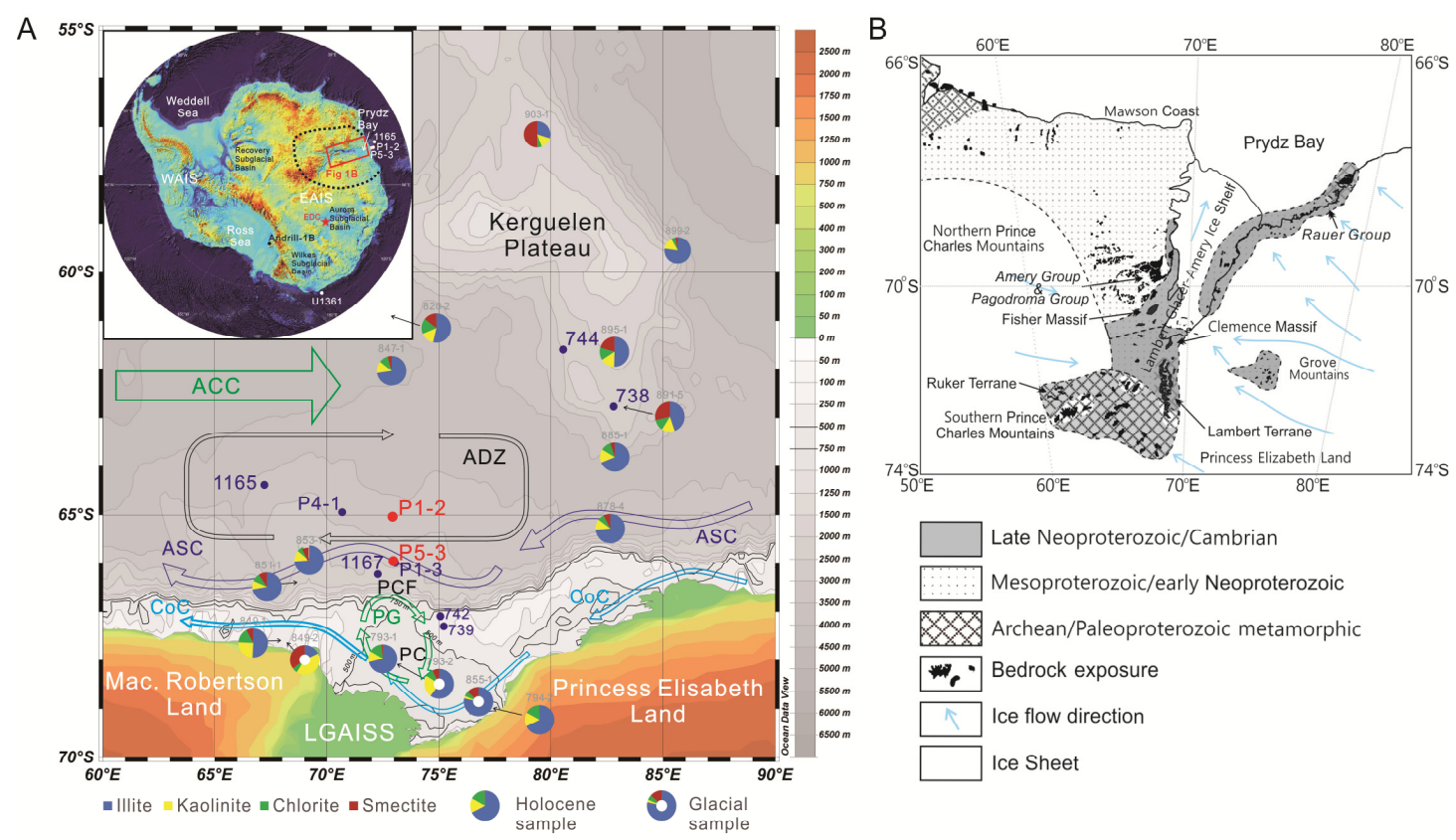

Fig. 1 (A) Environmental setting of the core sites. Pie charts show clay mineral compositions of marine surface sediment according to Borchers et al. (2011). Current systems are based on Shipboard Scientific Party (2001). ACC: Antarctic Circumpolar Current. ADZ: Antarctic Divergence Zone. ASC: Antarctic Slope Current. CoC: Coastal Current. PC: Prydz Channel. PCF: Prydz Channel Fan. PG: Prydz Gyre. Inset map shows the bedrock elevation of Antarctica (Fretwell et al., 2013) and the location of relevant sediment core and ice core records. EAIS: East Antarctic Ice Sheet. EDC: EPICA Dome C ice core (EPICA Community Members, 2004). WAIS: West Antarctic Ice Sheet. The area enclosed by the black dotted line is the LGAISS catchment. The red box indicates the region shown in Panel B. Sediment core sites and references are listed in Table 1. Maps were generated with Ocean Data View (R. Schlitzer, 2014, http://odv.awi.de). (B) Geological setting of the LGAISS after Mikhalsky et al. (2001), Ehrmann et al. (2003), and Van Leeuwen et al. (2019). The location of Amery Group and Pagodroma Group outcrops in the Northern Prince Charles Mountains is indicated. 


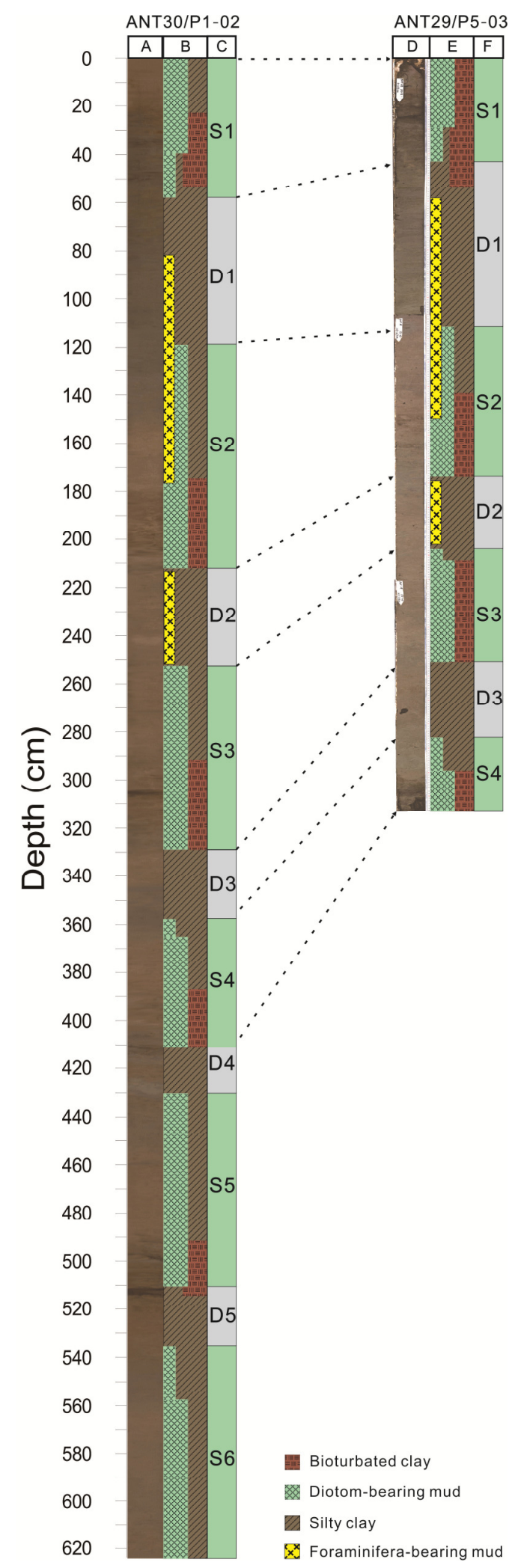

Fig. 2 Lithological comparison between sediment cores P1-2 and P5-3. (A) and (D): core images. (B) and (E): lithological logs. $(C)$ and $(F)$ : sediment facies. Facies S1-S6 and D1-D5 represent diatom-bearing units and diatom-free units, respectively. 


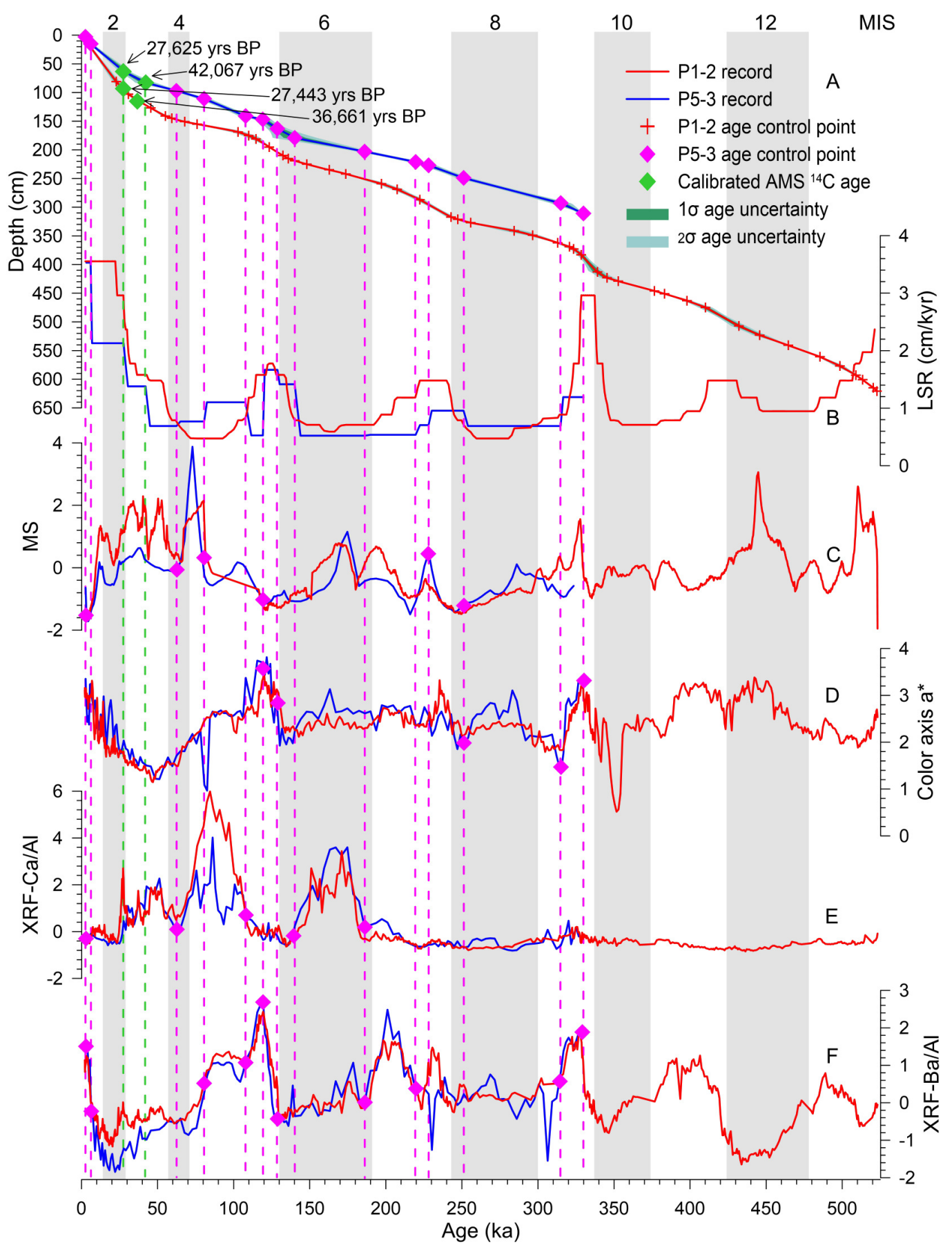

Fig. 3 Age models and sediment property records of sediment cores P1-2 and P5-3. (A) Age-depth models of cores P1-2 and P5-3. Age control points for core P5-3 are from Figure DR3 and Table 3 and for core P1-2 are from Wu et al. (2017). Age uncertainty was estimated using a bootstrap algorithm according to Xiao et al. (2016). (B) Linear sedimentation rate (LSR). (C) Magnetic susceptibility (MS). (D) Colour axis $a^{*}$. (E) XRF core scanning derived $\mathrm{Ca} / \mathrm{Al}$ and $(\mathrm{F}) \mathrm{XRF}$ core scanning derived Ba/Al. Red and blue records are from cores P1-2 and $\mathrm{P} 5-3$, respectively. The original magnitudes of the records in (C-F) have been diminished by normalisation to facilitate core-to-core comparison. Glacial intervals are shaded grey and labelled with MIS numbers according to Lisiecki and Raymo (2005). 

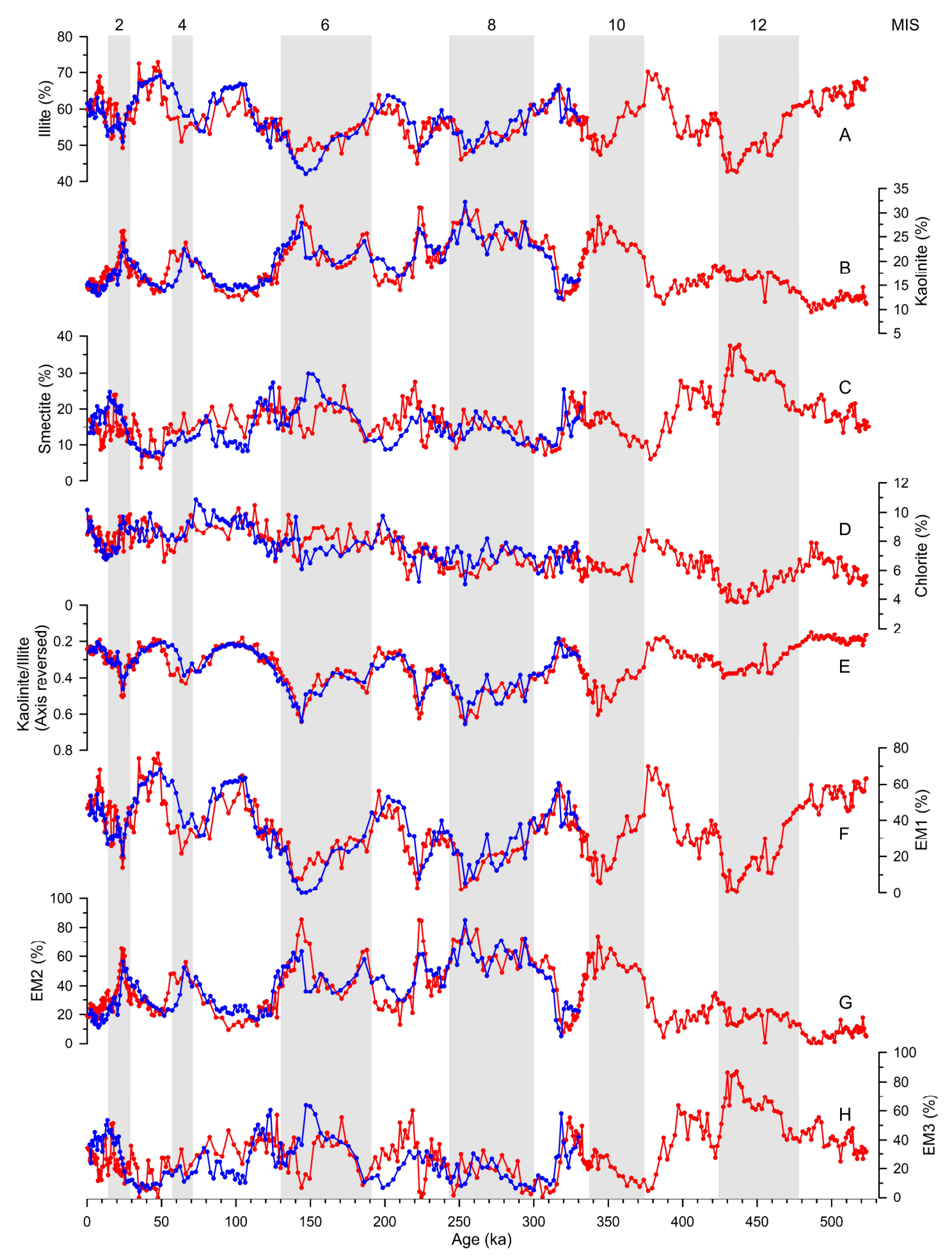

Fig. 4 Time series of (A-D) clay mineralogy, $(E)$ kaolinite/illite ratios (note reversed axis), and (F-H) end-members EM1-3 from the three-EM model (see Fig. 5) in cores P1-2 (red) and P5-3 (blue). Glacial intervals are shaded grey and labelled with MIS numbers according to Lisiecki and Raymo (2005). 

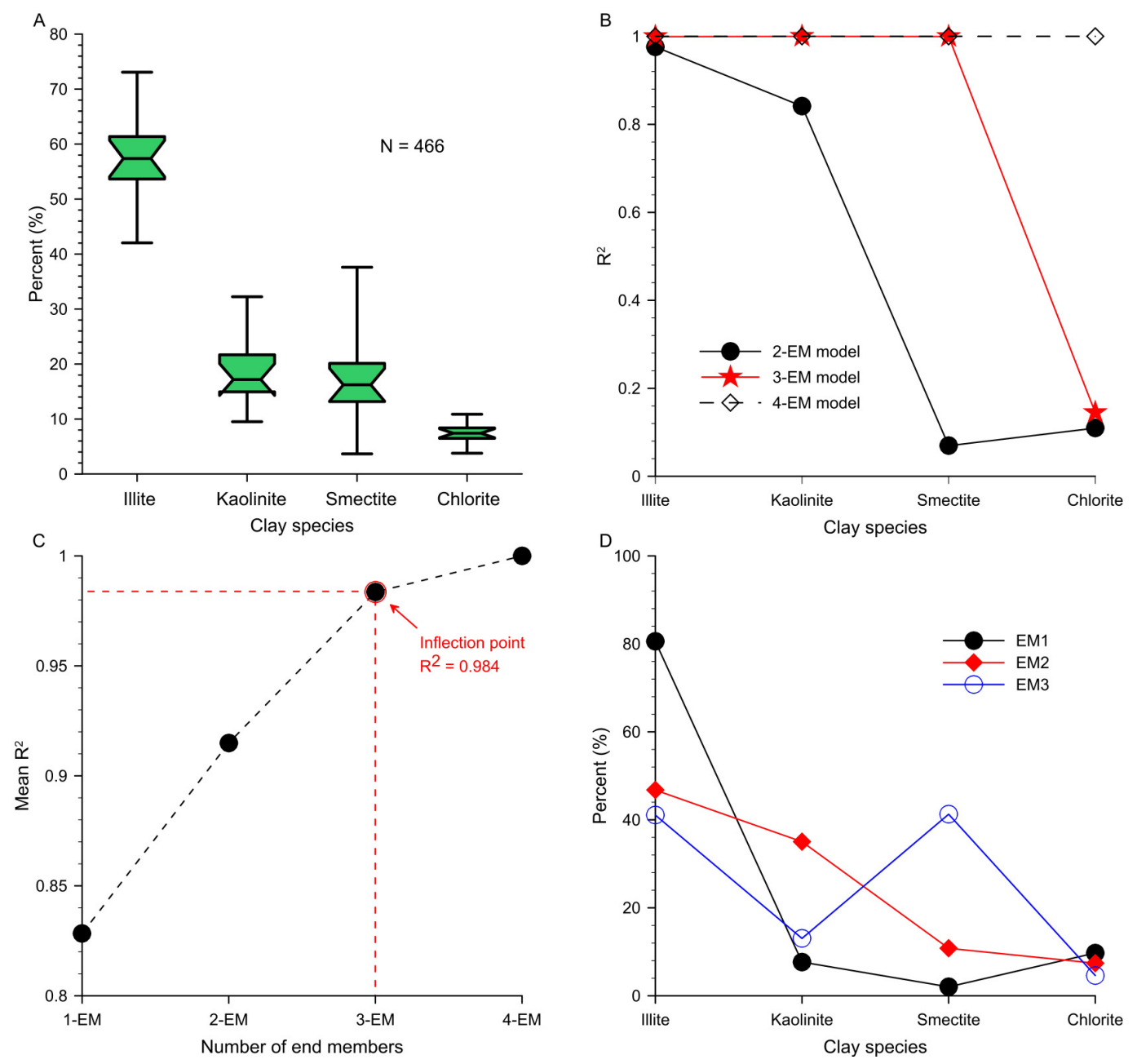

Fig. 5 End-member Modelling Analysis on clay mineral compositions of the core sediment $(\mathrm{N}=466)$. (A) Box-whisker plot of the clay mineral contents. The top and bottom whiskers show the maximum and minimum values, respectively. (B) Coefficients of determination $\left(R^{2}\right)$ for each clay species in models with two, three, or four EMMA-derived EMs. (C) Mean coefficients of determination $\left(R^{2}\right)$ for all clay species, weighted by abundance, in models with 1-4 EMs. The three-EM model (highlighted by a red circle) was selected as the best model to interpret the dataset. (D) Clay mineral compositions of the modelled EMs from the three-EM model. 

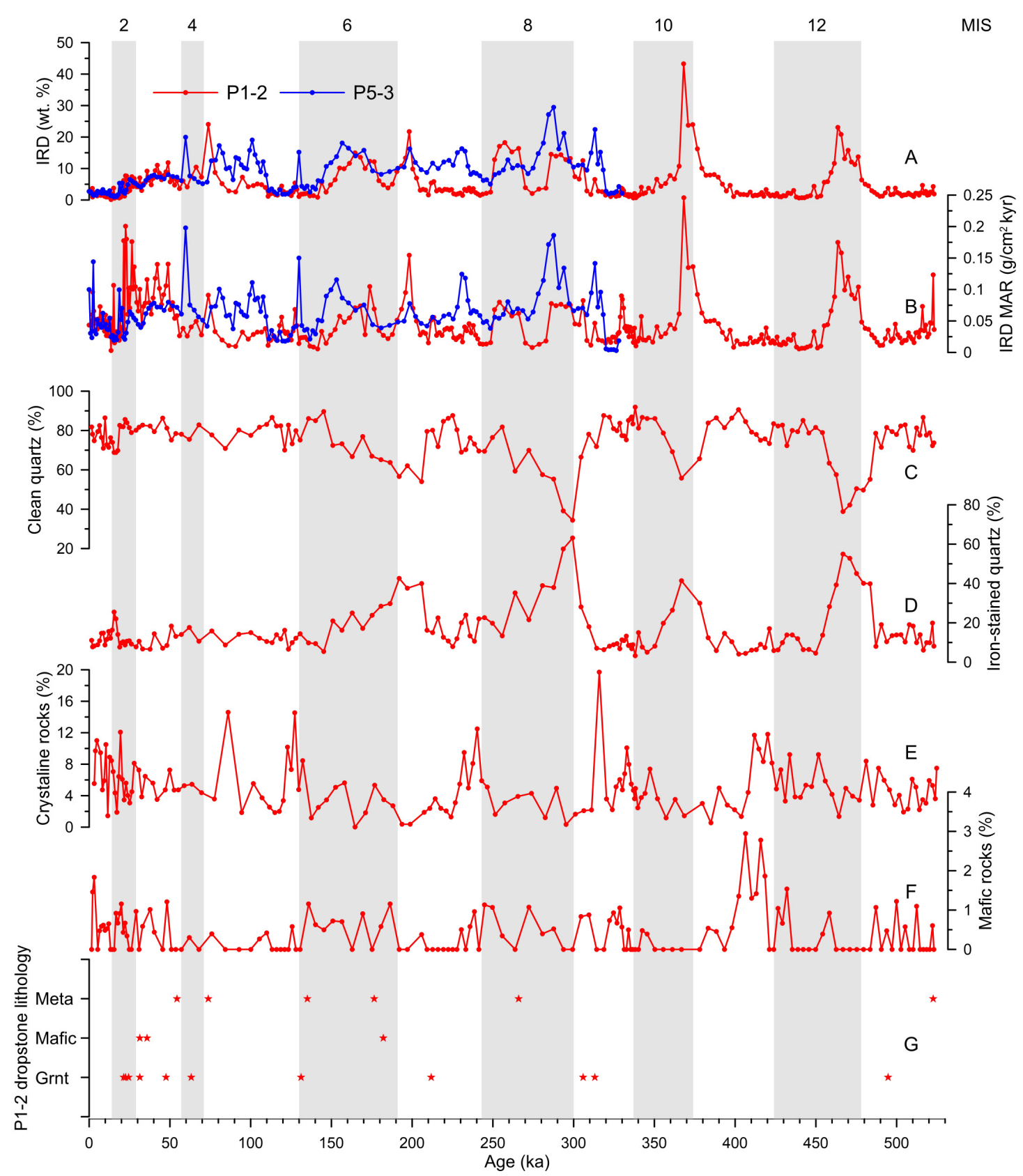

Fig. 6 Records of (A) IRD abundance (154-5000 $\mu \mathrm{m}$ fraction) and (B) IRD MAR from cores P1-2 (red) and P5-3 (blue), and lithological compositions of (C-F) IRD and (G) dropstones from core P1-2. Labels in (G) are: Grnt, granites; Mafic, mafic rocks; Meta, metamorphic rocks. Glacial intervals are shaded grey and labelled with MIS numbers according to Lisiecki and Raymo (2005). 

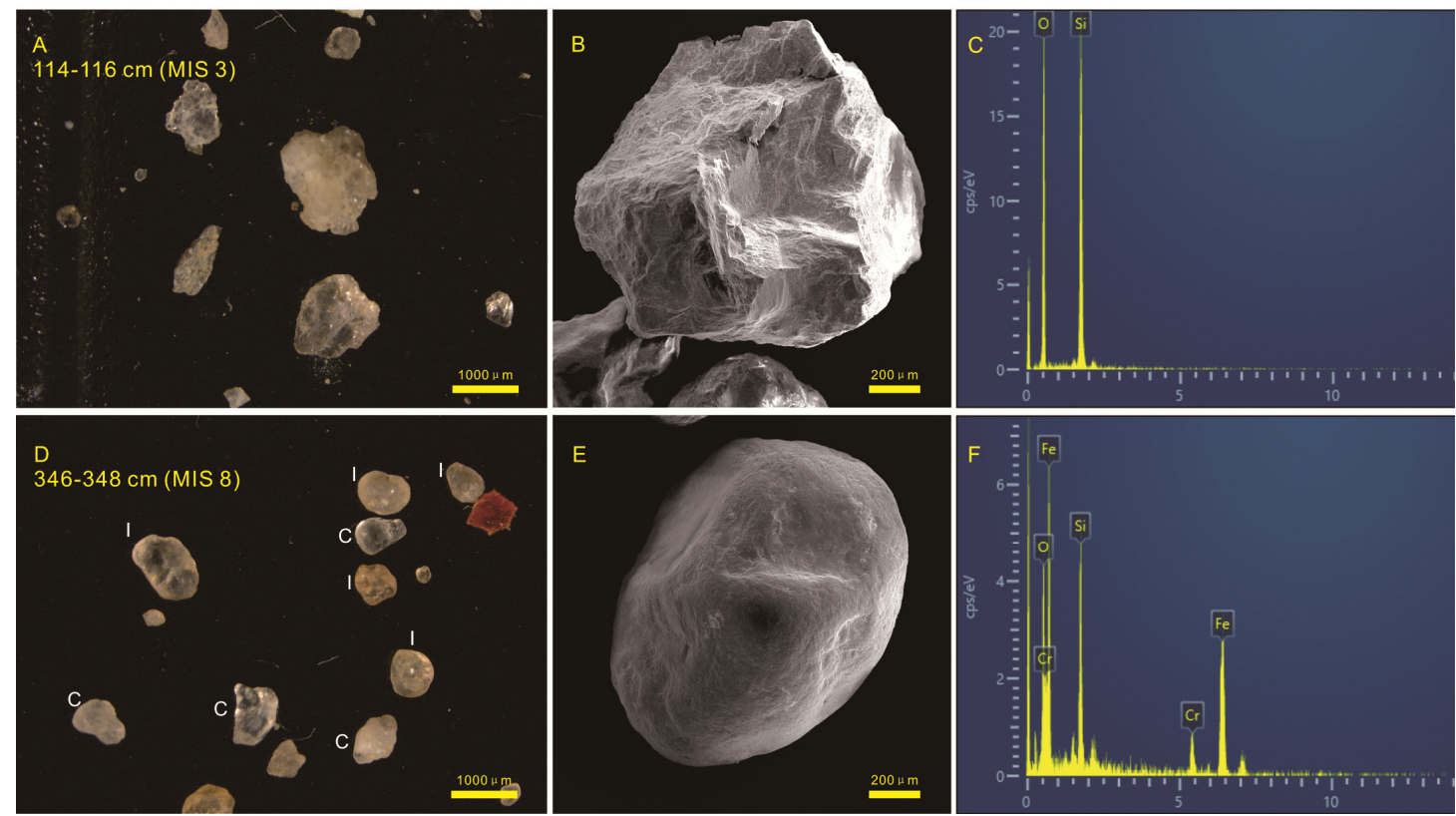

Fig. 7 Two varieties of quartz in the IRD fractions of core P1-2. (A) Angular to subangular clear quartz from core depth 114-116 cm (MIS 3). (B) and (C) Scanning electron microscope image and energy-dispersive spectrum of angular clear quartz from core depth 114-116 cm. (D) Subrounded to rounded iron-stained quartz (labelled I) with minor angular to subangular clear quartz (labelled C) from core depth 346-348 cm (MIS 8). (E) and (F) Scanning electron microscope image and energy-dispersive spectrum of rounded iron-stained quartz from core depth $346-348 \mathrm{~cm}$. 

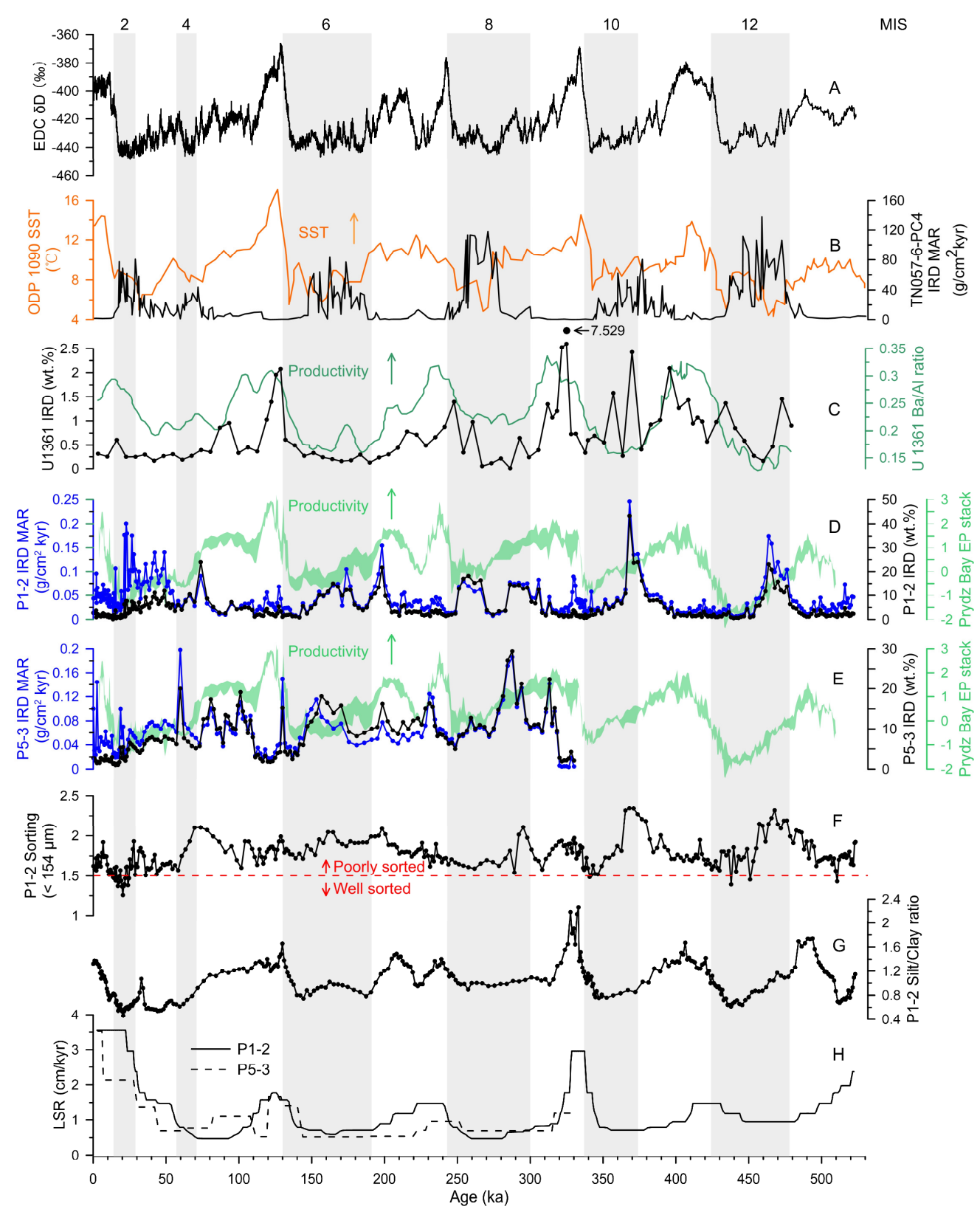

Fig. 8 Comparison of IRD records from the Southern Ocean. (A) Antarctic temperature proxy from EDC- $\delta D$ (EPICA Community Members, 2004). (B) IRD MAR (250-2000 $\mu \mathrm{m}$ fraction) from core TN057-6-PC4 (Teitler et al., 2010) and alkenone-based sea surface temperature (SST) from nearby ODP Site 1090 (Martínez-Garcia et al., 2009). (C) IRD abundance (250-2000 $\mu \mathrm{m}$ fraction) and XRF scanning-derived Ba/Al count ratio from IODP Site U1361 (Wilson et al., 2018) (see Fig. $1 A$ for core location). (D, E) IRD abundance and IRD MAR (154-5000 $\mu \mathrm{m}$ fraction) from cores P1-2 and P5-3, and normalised stack of Export Production (EP) records from Prydz Bay, derived from cores P1-2, P1-3, and P4-1 (see Fig. 1A for core locations) (Wu et al., 2017). (F) Sorting parameter ( $<154 \mu \mathrm{m}$ fraction) in core P1-2. Red dashed line indicates a value of 1.5, which separates poorly sorted and well sorted sediments (Folk and Ward, 1957). (G) Silt/clay ratio in core P1-2 (Wu et al., 2018). (H) Linear Sedimentation Rate (LSR) of cores P1-2 and P5-3. Glacial intervals are shaded grey and labelled with MIS numbers according to Lisiecki and Raymo (2005). 


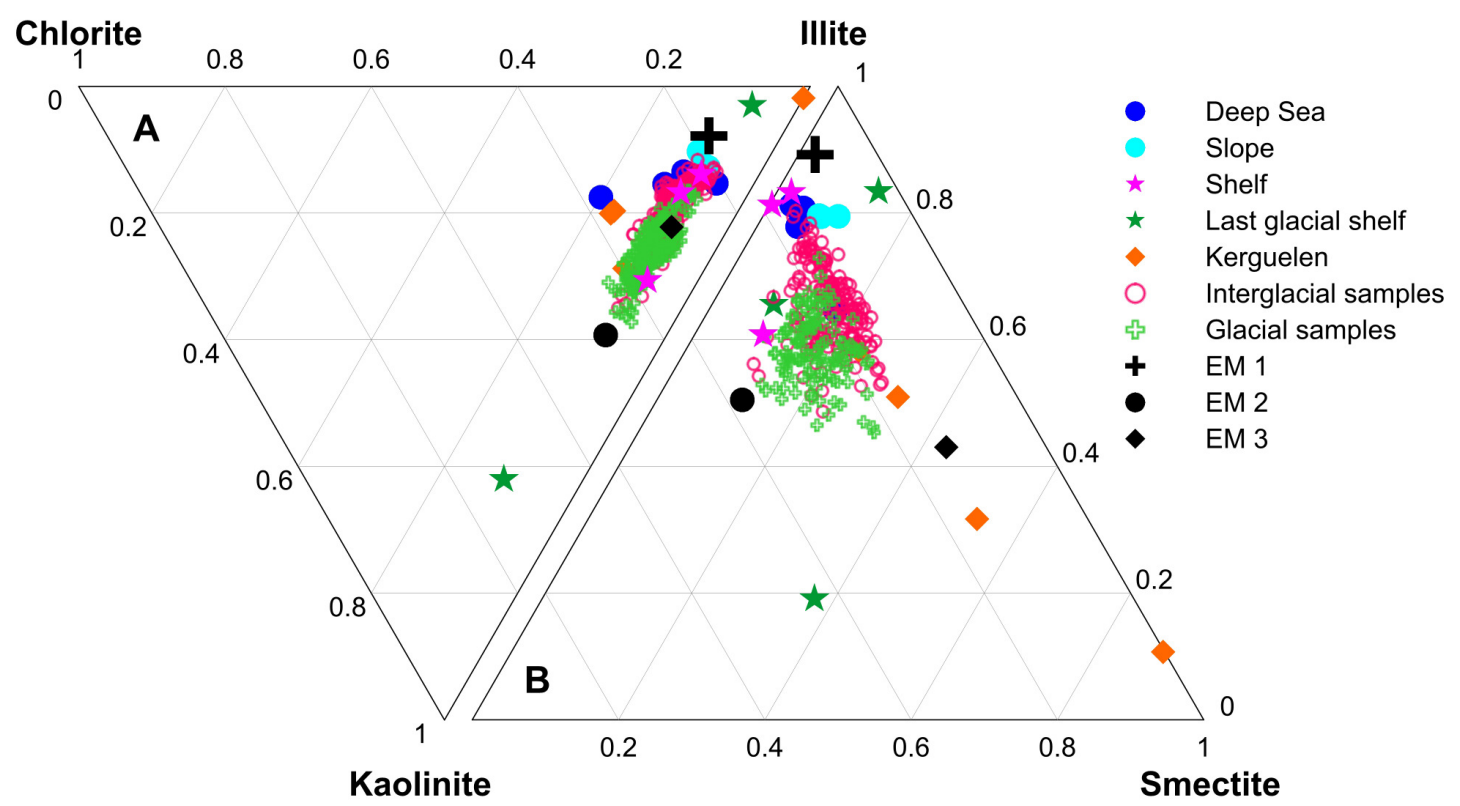

Fig. 9 Clay mineral provenance for downcore samples in cores P1-2 and P5-3 compared to surface sediment samples from Borchers et al. (2011) and modelled end-members (see Fig. 5). (A) Chlorite-Kaolinite-Illite plot. (B) Smectite-Kaolinite-Illite plot. EM: End-members from EMMA analysis. 

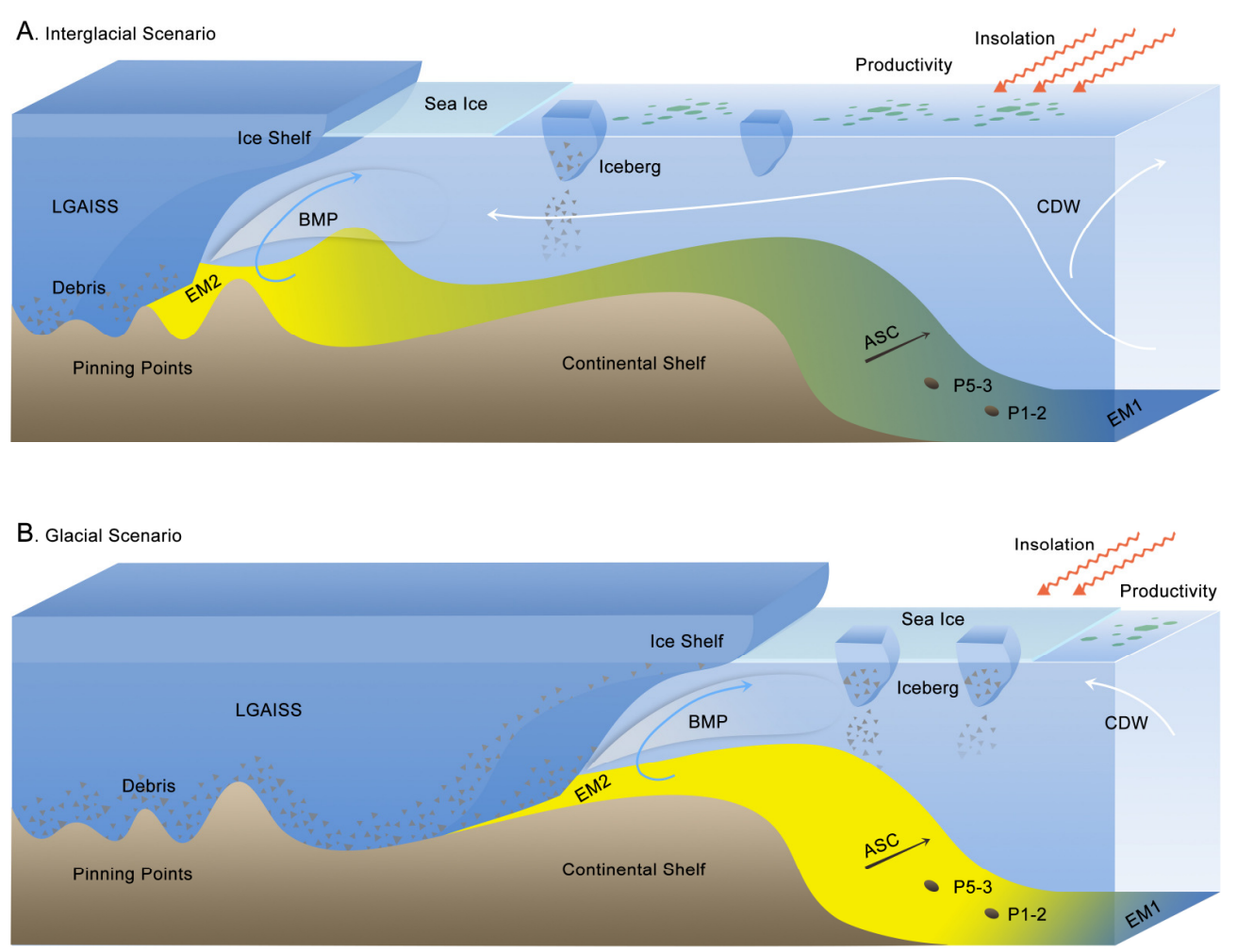

Fig. $10 \mathrm{~A}$ conceptual model to explain the relationship between the dynamic behaviour of the LGAISS and clay mineral compositions in the sediment cores. Panels (A) and (B) represent interglacial and glacial scenarios, respectively. Blue seafloor colour represents EM1 (illite-dominated, see Figs. 5D and 9), which is derived from multiple local and more distal sources and represents background clay mineral sedimentation in the study area. Yellow colour represents EM2 (kaolinite-rich, see Figs. 5D and 9), which is supplied by the LGAISS. The transition between blue and yellow represents variable mixing proportions of EM1 and EM2. In detail, EM2 is eroded from subglacial sources, transported by the ice sheet, and deposited near the grounding line due to local ice melting and subglacial meltwater inputs. Buoyant melt plumes and iceberg rafting can carry EM2 further towards the continental slope and rise. Not to scale. ASC: Antarctic Slope Current. BMP: Buoyant melt plume. CDW: Circumpolar Deep Water. 


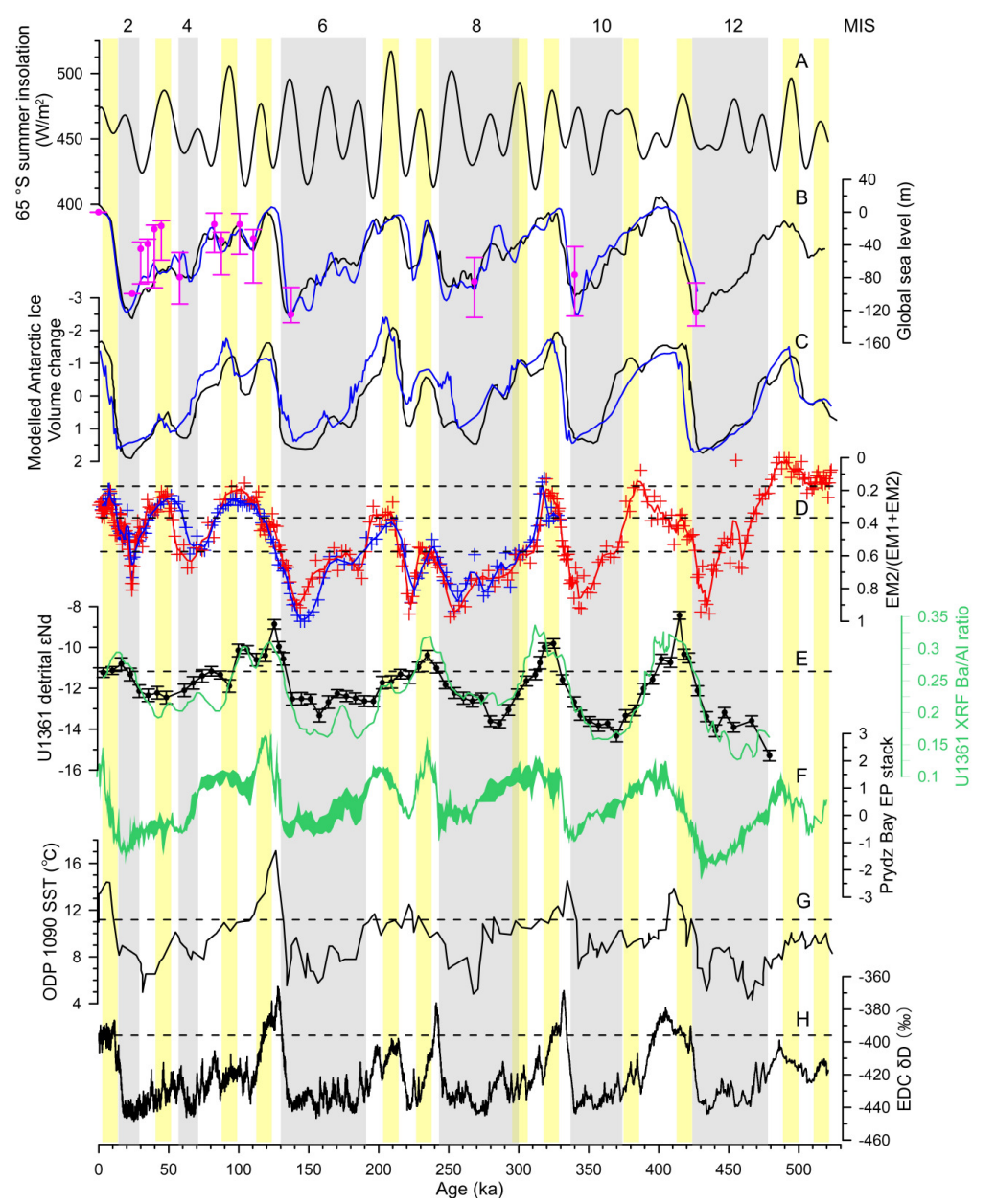

Fig. 11 LGAISS dynamics over the past $520 \mathrm{kyr}$ in a global climate context. (A) $65^{\circ} \mathrm{S}$ summer insolation (Laskar et al., 2004). (B) Global sea level reconstructions from Waelbroeck et al. (2002) (blue) and Spratt and Lisiecki (2016) (black). Purple dots with error bars indicate discrete sea level estimates from Batchelor et al. (2019). (C) Modelled time series of Antarctic Ice Volume change from Pollard and DeConto (2009) (blue) and Tigchelaar et al. (2018) (black), plotted as standard deviations from the mean. (D) Clay minerology (EM2/(EM1+EM2) ratio; note reversed axis) of cores P1-2 (red) and P5-3 (blue). Solid lines are 3-point running means. Black dashed lines indicate values that could reflect grounding line positions linked to pinning points (see main text). (E) Detrital neodymium isotope record $\left(\varepsilon_{N d}\right)$ from Site U1361 offshore of the Wilkes Subglacial Basin (black) and local productivity record based on $\mathrm{Ba} / \mathrm{Al}$ count ratio from XRF scanning (green) (Wilson et al., 2018) (see Fig. 1A for core location). Higher values of $\varepsilon \mathrm{Nd}$ and $\mathrm{Ba} / \mathrm{Al}$ indicate inland retreat of the ice sheet and higher marine productivity, respectively. The black dashed line indicates the core top $\varepsilon_{N d}$ value. (F) Normalised stack of Export Production (EP) records from Prydz Bay, derived from cores P1-2, P1-3, and P4-1 (see Fig. 1A for core locations) (Wu et al. 2017). (G) Southern Ocean sea surface temperature (SST) from alkenones at ODP Site 1090 (Martínez-Garcia et al., 2009). The black dashed line indicates the core top SST. (H) Antarctic temperature proxy from EDC-סD (EPICA Community Members, 2004). The black dashed line indicates the core top (modern) $\delta D$ values. Grey bars indicate glacial intervals and are labelled with MIS numbers (Lisiecki and Raymo, 2005). Yellow bars indicate intervals of maximum local summer insolation within interglacials. 
Table 1 Sediment cores used or referred to in this study

\begin{tabular}{|c|c|c|c|c|c|}
\hline Site & $\begin{array}{l}\text { Longitude } \\
\left({ }^{\circ} \mathrm{E}\right)\end{array}$ & $\begin{array}{l}\text { Latitude } \\
\left({ }^{\circ} \mathrm{S}\right)\end{array}$ & $\begin{array}{l}\text { Water depth } \\
\text { (m) }\end{array}$ & $\begin{array}{l}\text { Core length } \\
(\mathrm{cm})\end{array}$ & Data source \\
\hline ANT30/P1-02 & 72.94 & 65.01 & 2860 & 624 & $\begin{array}{l}\text { This study; Wu et al. (2017; } \\
\text { 2018; 2019; 2020) }\end{array}$ \\
\hline ANT29/P5-03 & 72.96 & 65.99 & 2576 & 313 & This study \\
\hline ANT30/P1-03 & 73.02 & 65.99 & 2542 & 599 & $\begin{array}{l}\text { Wu et al. (2017); Tang et al. } \\
\text { (2016) }\end{array}$ \\
\hline ANT29/P4-01 & 70.69 & 64.94 & 3162 & 421 & Wu et al. (2017) \\
\hline ODP 1165 & 67.22 & 64.38 & 3538 & - & Passchier (2011) \\
\hline ODP 1167 & 66.23 & 72.29 & 2354 & - & Passchier et al. (2003) \\
\hline ODP 739 & 75.05 & 67.16 & 412 & - & Hambrey et al. (1991) \\
\hline ODP 742 & 75.24 & 67.33 & 410 & - & Hambrey et al. (1991) \\
\hline ODP 738 & 82.79 & 62.71 & 2253 & - & Erhmann (1991) \\
\hline ODP 744 & 80.59 & 61.58 & 2307 & - & Erhmann (1991) \\
\hline AND-1B & 167.09 & 77.89 & 935 & - & McKay et al. (2012) \\
\hline IODP U1361A & 143.89 & 64.41 & 3454 & - & Wilson et al. (2018) \\
\hline TN057-6-PC4 & 8.98 & 42.93 & 3751 & - & Teitler et al. (2010) \\
\hline ODP 1090 & 8.90 & 42.88 & 3702 & - & Martínez-Garcia et al. (2009) \\
\hline
\end{tabular}


Table 2 AMS ${ }^{14} \mathrm{C}$ dating results on $N$. pachyderma (sin.) from cores P5-3 and P1-2

\begin{tabular}{|c|c|c|c|c|c|c|}
\hline Sample code & Core & $\begin{array}{l}\text { Depth } \\
(\mathrm{cm})\end{array}$ & $\begin{array}{l}\text { AMS }{ }^{14} \mathrm{C} \\
\text { age }(\mathrm{yr})\end{array}$ & $\begin{array}{l}\text { Reservoir } \\
\text { corrected } \\
{ }^{14} \mathrm{C} \text { age (yr) }\end{array}$ & $\begin{array}{l}\text { Calibrated } \\
\text { age* }(y r \\
\text { BP) }\end{array}$ & Data source \\
\hline BETA 381540 & P5-3 & $60-62$ & $24750 \pm 100$ & $23450 \pm 100$ & $27625 \pm 183$ & This study \\
\hline BETA 381541 & P5-3 & $82-84$ & $39050 \pm 390$ & $37750 \pm 390$ & $42067 \pm 554$ & This study \\
\hline BETA 381542 & P5-3 & $114-116$ & $>43500$ & - & - & This study \\
\hline BETA 381544 & P5-3 & 204-206 & $>43500$ & - & - & This study \\
\hline BETA 395571 & $\mathrm{P} 1-2$ & $92-94$ & $24710 \pm 110$ & $23410 \pm 110$ & $27443 \pm 223$ & $\begin{array}{l}\text { Wu et al. } \\
(2017)\end{array}$ \\
\hline BETA 400276 & $\mathrm{P} 1-2$ & $114-116$ & $34050 \pm 240$ & $32750 \pm 240$ & $36661 \pm 355$ & $\begin{array}{l}\text { Wu et al. } \\
(2017)\end{array}$ \\
\hline BETA 400277 & P1-2 & $136-138$ & $>43500$ & - & - & $\begin{array}{l}\text { Wu et al. } \\
(2017)\end{array}$ \\
\hline BETA 395573 & $\mathrm{P} 1-2$ & $162-164$ & $>43500$ & - & - & $\begin{array}{l}\text { Wu et al. } \\
(2017)\end{array}$ \\
\hline BETA 395574 & $\mathrm{P} 1-2$ & $226-228$ & $>43500$ & - & - & $\begin{array}{l}\text { Wu et al. } \\
(2017)\end{array}$ \\
\hline
\end{tabular}

${ }^{*}$ A reservoir age of $1300 \mathrm{yr}$ was applied (Domack et al., 2001) and calibration used Calib 7.0 program (Stuiver and Reimer, 1993) and Marine 13 calibration curve (Reimer et al., 2013). 
Table 3 Age-depth control points for core P5-3

\begin{tabular}{rrrl}
\hline No. & Depth $(\mathrm{cm})$ & \multicolumn{1}{c}{ Age $(\mathrm{ka})$} & Sources \\
\hline 1 & 61 & 27.6 & AMS ${ }^{14} \mathrm{C}$ \\
2 & 83 & 42.1 & AMS ${ }^{14} \mathrm{C}$ \\
3 & 6 & 2.6 & XRF Ba/Al; XRF Ca/Al; MS \\
4 & 15 & 6.0 & XRF Ba/Al \\
5 & 97 & 62.4 & XRF Ca/Al; MS \\
6 & 111 & 80.6 & XRF Ba/Al; MS \\
7 & 141 & 107.8 & XRF Ba/Al; XRF Ca/Al \\
8 & 147 & 119.2 & XRF Ba/Al; $a^{*} ; \mathrm{MS}$ \\
9 & 163 & 128.8 & XRF Ba/Al; $a^{*}$ \\
10 & 179 & 140.1 & XRF Ca/Al \\
11 & 203 & 186.1 & XRF Ba/Al; XRF Ca/Al \\
12 & 221 & 219.6 & XRF Ba/Al \\
13 & 227 & 228.1 & MS \\
14 & 249 & 251.1 & $a^{*} ; \mathrm{MS}$ \\
15 & 293 & 314.9 & XRF Ba/Al; $a^{*}$ \\
16 & 311 & 330.0 & XRF Ba/Al; a*
\end{tabular}

Note: MS, magnetic susceptibility 
Appendix to: Late Quaternary dynamics of the Lambert Glacier-Amery Ice Shelf system, East Antarctica

Li Wu', David J. Wilson², Rujian Wang ${ }^{1}$, Sandra Passchier ${ }^{3}$, Wout Krijgsman ${ }^{4}$,

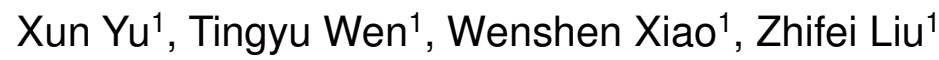

1. State Key Laboratory of Marine Geology, Tongji University, Shanghai, China

2. Institute of Earth and Planetary Sciences, University College London and

Birkbeck, University of London, London, UK

3. Department of Earth and Environmental Studies, Montclair State University, Upper Montclair, New Jersey, USA

4. Department of Earth Sciences, Utrecht University, Utrecht, The Netherlands 


\section{Supplementary Figures}
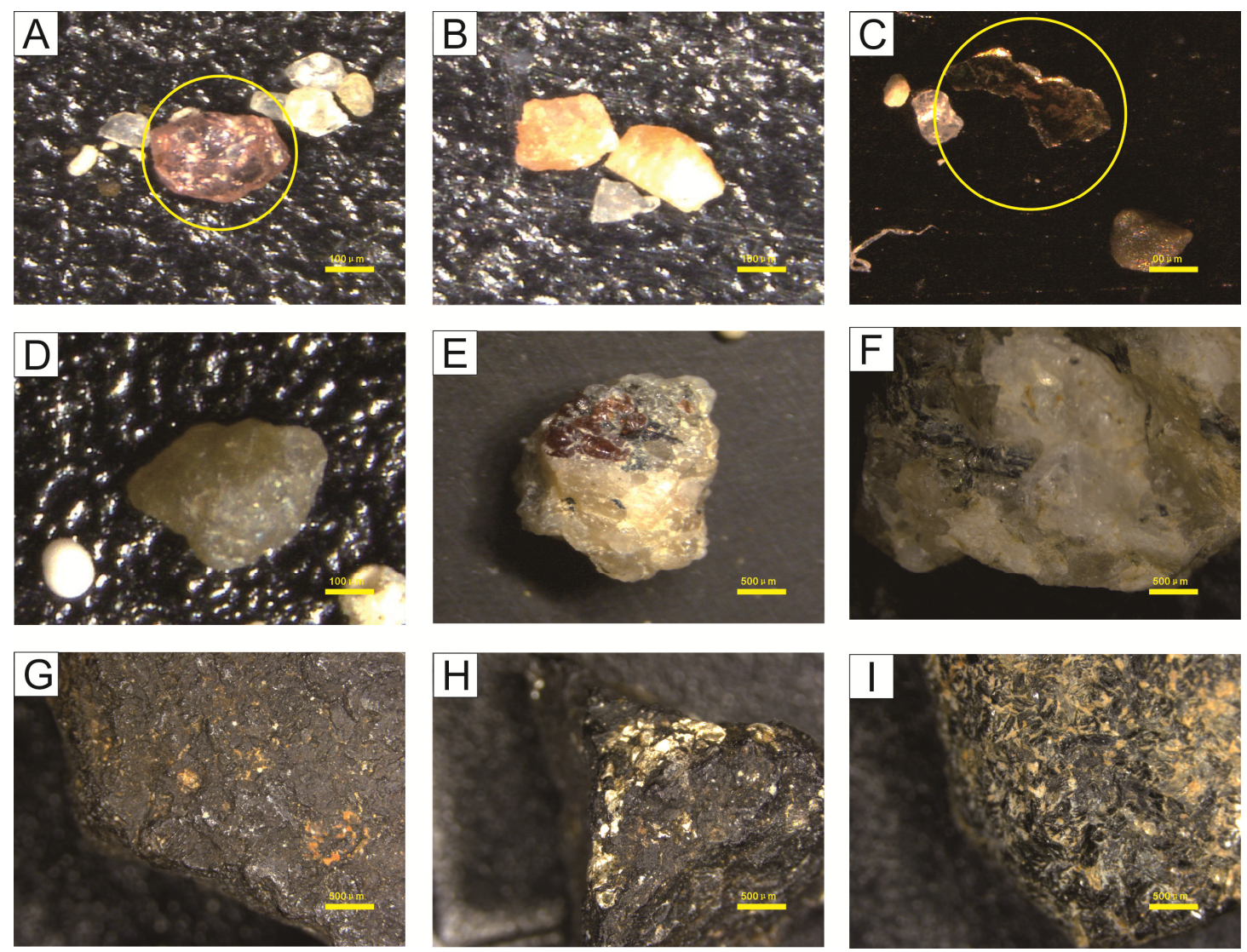

Figure DR1 Lithology of IRD and dropstones. (A) Garnet, circled. (B) Feldspar. (C) Biotite, circled. (D) Chert. (E) Garnet-bearing metamorphic rock. (F) Granite. (G) Mafic metamorphic rock. (H) Biotite-bearing mafic metamorphic rock. (I) Dolerite. 


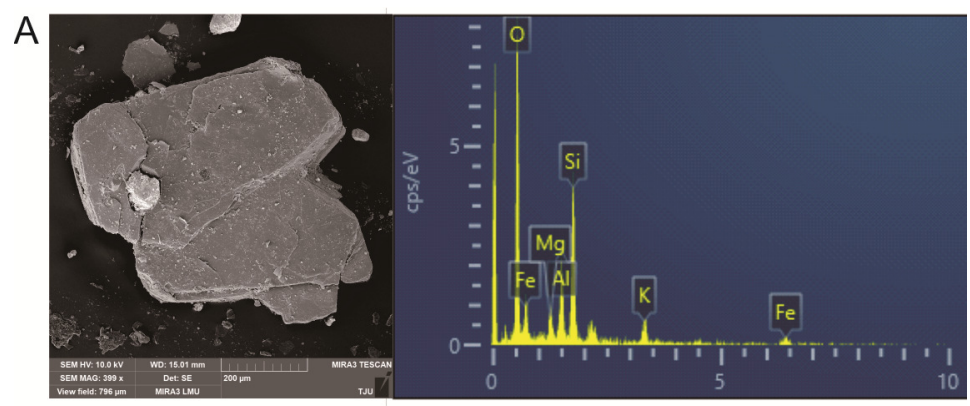

$\mathrm{B}$
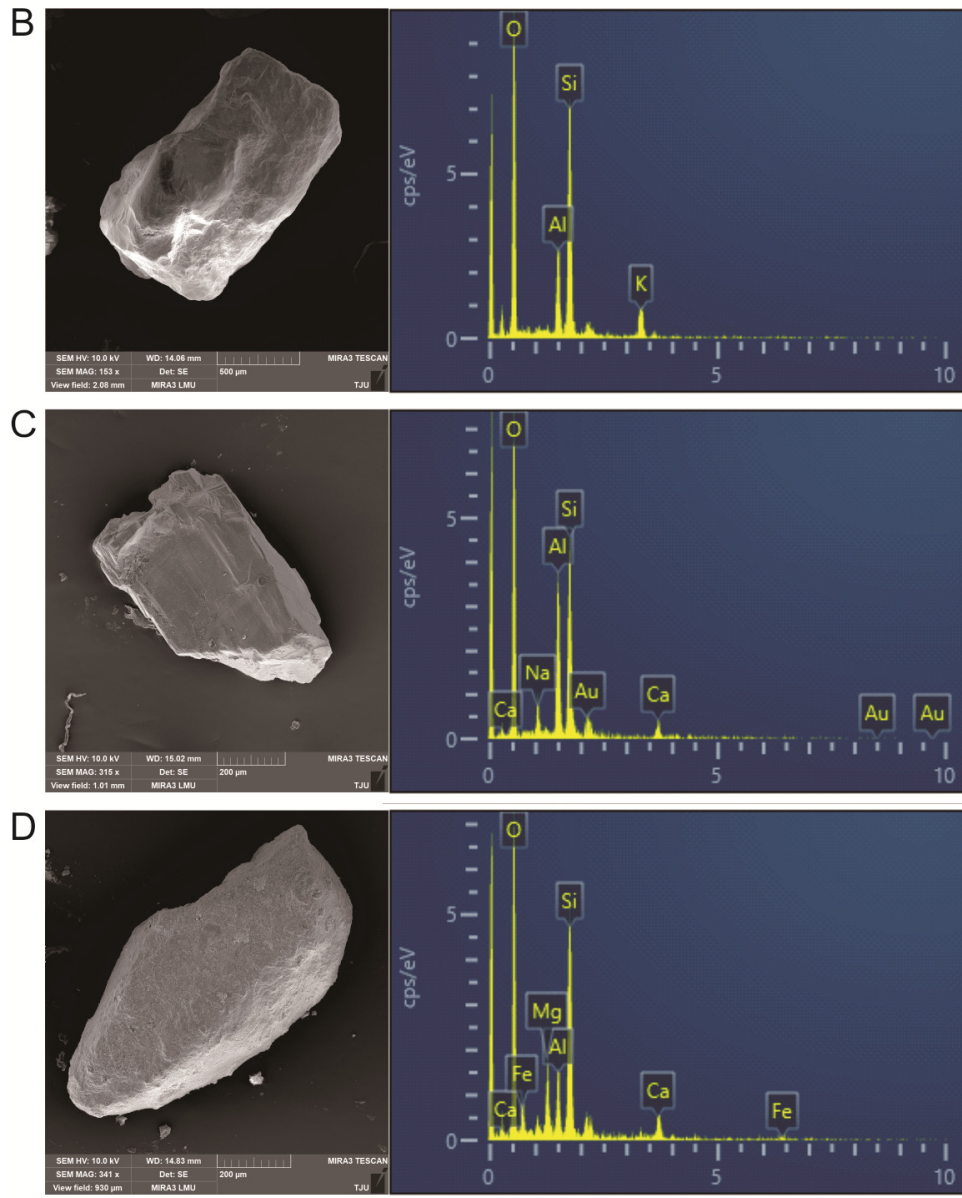

Figure DR2 Scanning electron microscope images and energy-dispersive spectra of IRD grains. (A) Biotite. (B) K-feldspar. (C) Plagioclase. (D) Garnet. 

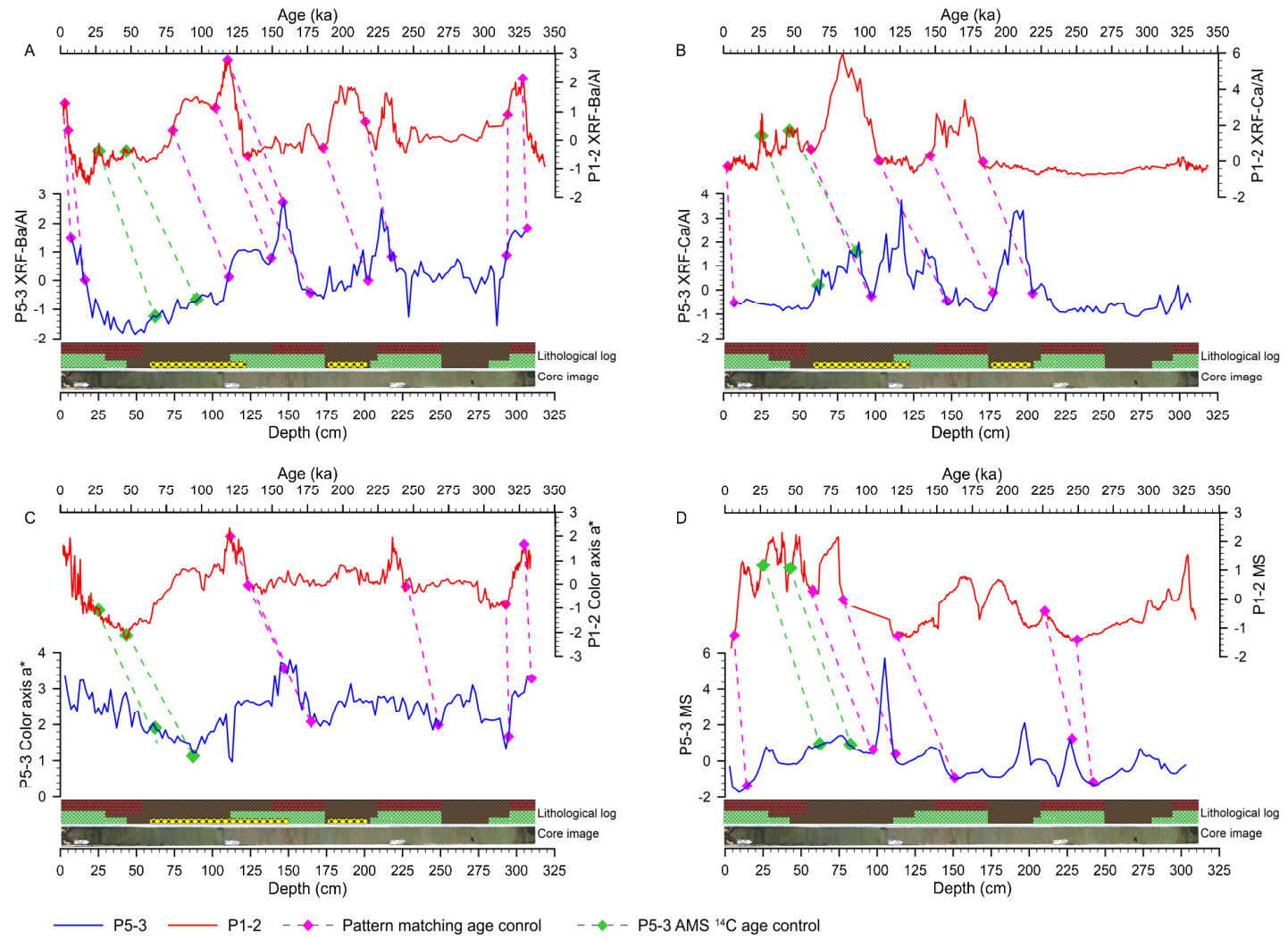

Figure DR3 Comparison of sediment property records between sediment cores P5-3 (blue, lower axis with depth scale) and P1-2 (red, upper axis with age scale) to determine age controls for core P5-3. Magenta diamonds joined by dashed lines indicate inter-core correlations based on pattern matching. Green diamonds joined by dashed lines are correlations between the two AMS ${ }^{14} \mathrm{C}$ ages in core P5-3 and their corresponding tuned ages in core P1-2. Lithological logs and core images are shown for core P5-3 (see Fig. 2 for key). MS, magnetic susceptibility. The records have been normalised to facilitate core-to-core comparison. 


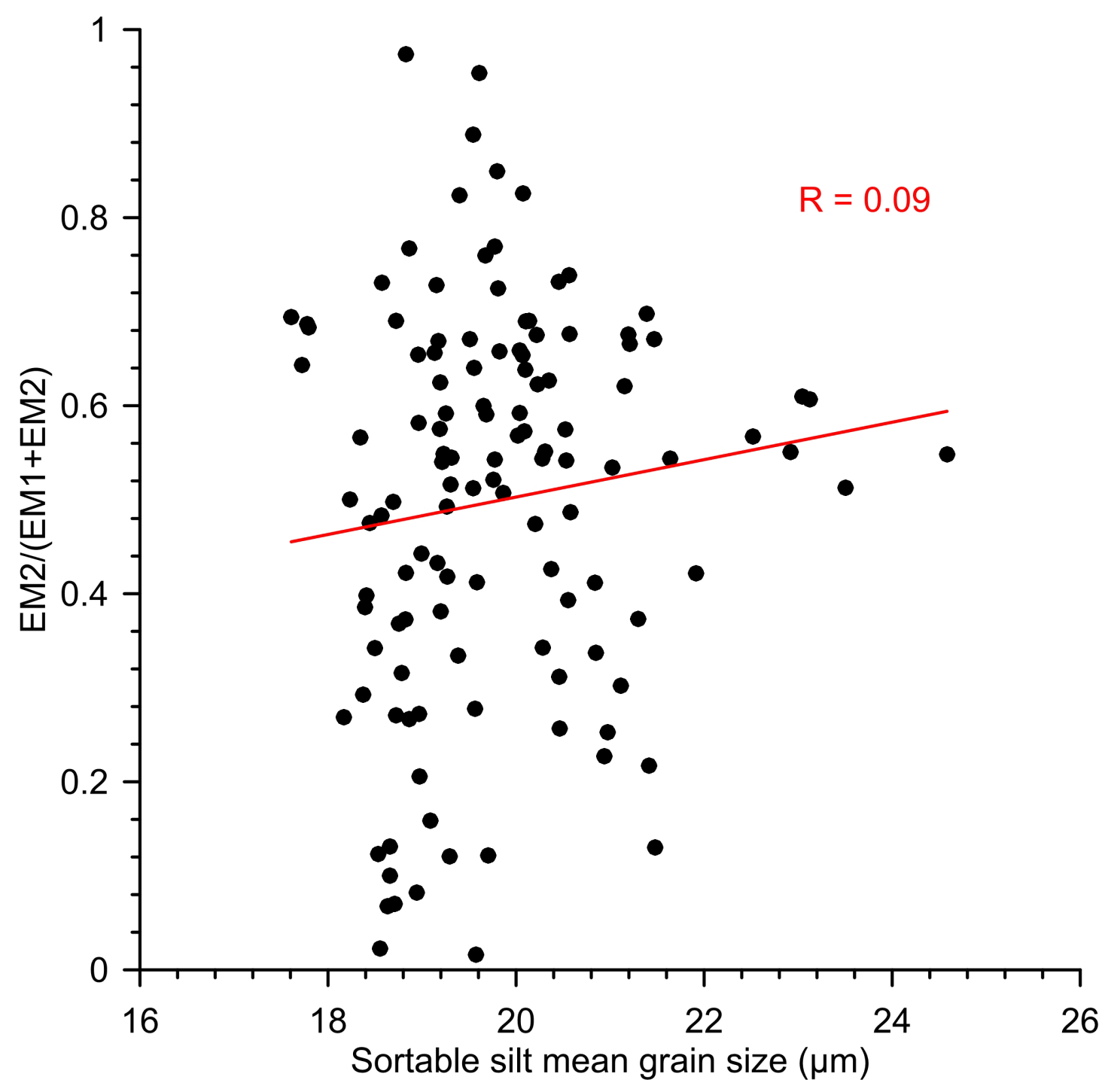

Figure DR4 Plot of clay mineral proxy EM2/(EM1+EM2) versus sortable silt mean grain size in sediment core P1-2, demonstrating no correlation between the two proxies. Grain size data were from Wu et al. (2018), and sortable silt mean grain size was calculated after Wu et al. (2020) according to McCave and Andrews (2019). Only the data with a 7-point running correlation coefficient between the sortable silt mean grain size and the sortable silt percent (R7) above 0.5 , which is indicative of current-sorting, are included in this plot $(\mathrm{N}=146)$. 


\section{Supplementary Datasets}

Dataset DR1 XRF Ba_Al ratio Ca_Al ratio color a parameter magnetic susceptibility of core P5-3.xls

Dataset DR2 Magnetic susceptibility of core P1-2.xls

Dataset DR3 Clay mineral compositions of cores P1-2 and P5-3.xls

Dataset DR4 Iceberg rafted debris of cores P1-2 and P5-3.xls

Dataset DR5 Lithology of iceberg rafted debris and dropstones of core P1-2.xls 